\title{
Asymmetric flow field flow fractionation methods for virus purification
}

\author{
Eskelin, Katri Johanna
}

2016

Eskelin , K J , Lampi , M , Meier , F, Moldenhauer , E, Bamford, D H \& Oksanen , H M 2016, ' Asymmetric flow field flow fractionation methods for virus purification ' , Journal of pÿChromatography. A , vol. 1469 , pp. 108119 . https://doi.org/10.1016/j.chroma.2016.09.055

http://hdl.handle.net/10138/297759

https://doi.org/10.1016/j.chroma.2016.09.055

cc_by_nc_nd

acceptedVersion

Downloaded from Helda, University of Helsinki institutional repository.

This is an electronic reprint of the original article.

This reprint may differ from the original in pagination and typographic detail.

Please cite the original version. 


\section{Asymmetric flow field flow fractionation methods for virus purification}

2 Katri Eskelin ${ }^{1}$, Mirka Lampi ${ }^{1}$, Florian Meier ${ }^{2}$, Evelin Moldenhauer ${ }^{2}$, Dennis H. Bamford ${ }^{1}$,

3 and Hanna M. Oksanen ${ }^{1 *}$

4 'Department of Biosciences and Institute of Biotechnology,

5 Viikinkaari 9,

6 University of Helsinki,

$7 \quad$ FIN-00014 Helsinki, Finland

8

9 2Postnova Analytics

10 Max-Planck-Str. 14

1186899 Landsberg, Germany

12 * Corresponding author: hanna.oksanen@helsinki.fi, Tel.: +358-294-159-104; Fax: +358-

$13 \quad 294-159-098$.

\section{Abstract}

Detailed biochemical and biophysical characterization of viruses requires viral preparations

17 of high quantity and purity. The optimization of virus production and purification is an

18 essential, but laborious and time-consuming process. Asymmetric flow field flow

19 fractionation (AF4) is an attractive alternative method for virus purification because it is a

20 rapid and gentle separation method that should preserve viral infectivity. Here we

21 optimized the AF4 conditions to be used for purification of a model virus, bacteriophage

22 PRD1, from various types of starting materials. Our results show that AF4 is well suited for 
PRD1 purification as monitored by virus recovery and specific infectivity. Short analysis time and high sample loads enabled us to use AF4 for preparative scale purification of PRD1. Furthermore, we show that AF4 enables the rapid real-time analysis of progeny virus production in infected cells.

\section{Highlights}

- Virus remained infectious during gentle AF4 analysis.

- AF4 purification efficiently separated host-derived impurities and viruses.

- AF4 purification yielded purity comparable to traditional ultracentrifugation methods.

- Use of $250 \mu \mathrm{m}$ spacer eliminated the dilution of lysate samples during AF4.

- AF4 enables real-time analysis of progeny virus production in infected cells.

\section{Keywords}

Membrane virus, icosahedral virus, bacteriophage PRD1, monolithic chromatography, ultracentrifugation, real-time analysis of progeny virus production

\section{Introduction}

Viruses that infect animals and plants generally receive more attention than do viruses of prokaryotes (bacteria and archaea) because of their medical, agricultural, and economic importance. However, prokaryotic viruses have an immense effect on global microbial communities and consequently on Earth's biogeochemical cycles and climate [1-5]. The current estimate for virus abundance in sea water is $\sim 10^{30}[1]$ and similar numbers have been proposed for soil [6]. Still relatively few prokaryotic viruses are known in molecular, structural, and biochemical detail. Such knowledge is essential for interpreting viral diversity at the genomic and structural level and for understanding viral roles in every 
ecosystem. It is worth mentioning here that our current knowledge of many cellular processes, including transcription, translation, DNA replication, protein sorting, etc., stems from research on prokaryotic viruses. In addition, many commercially available enzymes vital for contemporary molecular biology, including ligases, restriction enzymes and polymerases, originated from prokaryotic viruses.

Further basic and applied research on viruses requires samples of high purity in quantity. After optimised production, the first purification step typically involves precipitation or filtration [7, 8]. Precipitation is applicable to high sample volumes where it can simultaneously concentrate and purify the viruses [8]. Downstream purification steps to remove impurities that co-precipitate with the virus particles due to similar biophysical and/or biochemical properties most commonly involve ultracentrifugation $[9,10]$. Depending on the ultracentrifugation method used, virus purification is achieved based on its sedimentation coefficient (rate zonal), buoyant density (isopycnic), or flotation [10]. A final purification step, such as differential ultracentrifugation or ultrafiltration, removes the gradient material and concentrates the viruses.

While ultracentrifugation methods often result in high purity virus preparations, recovery yields can be low [8] (see also Fig. S9). Therefore, preparative centrifugation of viruses 6 requires expensive ultracentrifuge farms. Moreover, the viscous and hyperosmotic nature 7 of some gradient media (e.g., sucrose, $\mathrm{CsCl}$ ) combined with the strong shear forces 8 generated during high speed centrifugation can damage viruses and lead to loss of 9 infectivity [8]. Alternative methods have also been developed as reviewed in [8, 9]. Anion exchange chromatography using monolithic columns has proven efficient for purification of 
71 large biomolecules such as viruses [11-13]. The macroporous nature of these monoliths

72 provides high surface accessibility for large molecules [13]. However, elution by increasing

73 ionic strength can be harmful to some sensitive viruses and is unusable in the case of

74 halophilic viruses that require high salt concentrations for infectivity [14].

75

Asymmetric flow field flow fractionation (AF4) is a subtechnique developed from field flow fractionation (FFF) methods. Its principles and theory have been described in the original papers [15] [16] [17] [18] and are summarized in many reviews [19-23]. In AF4, sample separation takes place in a trapezoidal flat channel under the influence of two flows: the channel flow $\left(V_{\text {out }}\right)$ that has a parabolic profile and the cross-flow $\left(V_{c}\right)$ that drives sample components towards the accumulation wall. This force is counteracted by the diffusion of sample components away from the wall. As a result, each sample component equilibrates at a distance from the accumulation wall that depends on its diffusion coefficient (D) and hydrodynamic molecular size $[15,16]$. In the normal separation mode smaller sample components elute before larger ones. Normal separation mode applies to sample components smaller than $\sim 1 \mu \mathrm{m}[20]$.

The omission of the stationary phase in AF4 decreases the pressure and shear forces during separation. In addition, the mobile phase composition can be readily modified to meet the demands of the sample components. As a result, AF4 is a gentle separation method that enables the analyzed molecules to retain their native conformation. AF4 has been successfully applied to various types of biological specimens $[20,22,24]$ as well as in studies of particles and colloids of non-biological origin [25]. Viruses were among the first specimens analyzed when field flow fractionation was introduced in 1976 [15]. Already 
in 1977 symmetric field flow fractionation was applied to determine the diffusion coefficients of bacteriophages Q 3 , f2, MS2, P22 and $\phi X 174$ [26]. Nowadays, however, AF4 [16] has replaced symmetric flow field flow fractionation. It has been used to study the particle size, size distribution and particle counts of viruses $[27,28]$ and virus-like particles (VLPs) [29-32]. AF4 has also shown its potential for determining the changes in the size distribution of VLPs upon assembly from purified modified viral protein components as well as the effect of encapsidation of heterologous DNA [30,31]. In addition, viruses have been utilized in experiments validating AF4 theory and performance $[17,18]$. However, although the potent of AF4 for purification of macromolecules, such as viruses, has been recognized, no published reports on the utilization of AF4 for large scale virus purification exists.

In this work, our goal was to develop a preparative scale fractionation procedure that would provide high purity accompanied by high yields of infectious viruses. We also compared AF4 to the established virus purification methods. We chose bacteriophage PRD1 [33] as our model virus as it already has an array of well-established purification methods $[11,34,35]$ enabling comparisons on purification methods efficacy. PRD1 has an icosahedral, proteinaceous capsid with a diameter of $\sim 66 \mathrm{~nm}$ and molecular mass of $\sim 66 \mathrm{MDa}$. Virions are decorated with $\sim 20 \mathrm{~nm}$ spikes at the five-fold symmetry axes. An internal membrane lies just inside the protein shell and encloses the double-stranded DNA genome [36-39]. Here we determined the optimal AF4 operation conditions for PRD1 and analyzed its purification using various types of starting materials. We also combined AF4 with monolithic anion chromatography. Both AF4 and monolithic anion chromatography were then compared to traditional ultracentrifugation methods. Our results demonstrate 
119 that AF4 has great potential for the purification of infectious viruses. Furthermore, we show

120 that AF4 enables rapid real-time analysis of progeny virus production in infected cells.

\section{Materials and methods}

\subsection{Sample preparation}

124

Bacteriophage PRD1 was cultured and purified as previously described [35]. The host Salmonella enterica serovar Typhimurium LT2 DS88 [40] was grown in Luria-Bertani medium (LB) at $37^{\circ} \mathrm{C}$. Cells in logarithmic growth phase were infected using a multiplicity of infection (MOI) of 10 . Cell lysis was detected by measuring culture turbidity at $550 \mathrm{~nm}$ (Chlormic, JP Selecta S.A., Barcelona, Spain). In specific cases, the culture was treated after lysis with DNase I (50 $\mu \mathrm{g} / \mathrm{mL}$; Sigma-Aldrich) or RNase A (30 $\mu \mathrm{g} / \mathrm{mL}$; Roche) for $1 \mathrm{~h}$ at $37^{\circ} \mathrm{C}$. Subsequent centrifugation (Sorval rotor SLA1500/3000, $8000 \mathrm{rpm}, 20 \mathrm{~min}, 4^{\circ} \mathrm{C}$ ) removed cell debris to yield the cleared lysate. Viruses were precipitated from the lysate using 10\% (w/v) polyethylene glycol (PEG) 6000 and $0.5 \mathrm{M} \mathrm{NaCl}$, collected by centrifugation as above, and resuspended in a small amount of buffer ( 0.01 of the initial volume) to yield PEG-PRD1. Standard virus buffer (20 mM potassium phosphate [pH 7.2], $1 \mathrm{mM} \mathrm{MgCl}_{2}$ ) was used in all purification steps. The resuspended viruses were purified by rate zonal centrifugation with a linear 5-20\% (w/v) sucrose gradient (Sorvall rotor AH629, $\left.24000 \mathrm{rpm}, 55 \mathrm{~min}, 5^{\circ} \mathrm{C}\right)$. Zones containing mature infectious viruses were collected by differential centrifugation (Sorvall rotor T647.5, $32000 \mathrm{rpm}, 3 \mathrm{~h}, 5^{\circ} \mathrm{C}$ ) and resuspended in virus buffer yielding 1xPRD1. Alternatively, further purification of the zones by an additional buoyant density centrifugation in $20-70 \%$ sucrose gradients (Sorvall rotor AH629, $\left.24000 \mathrm{rpm}, 20 \mathrm{~h}, 15^{\circ} \mathrm{C}\right)$ followed by differential centrifugation as above yielded 2XPRD1 purified to homogeneity (see also Fig. S9A). 
145 The AF4 experiments were carried out using an AF2000 MT instrument (Postnova 146 Analytics, Landsberg, Germany) equipped with a solvent organizer (PN7140), a solvent 147 degasser (PN7520), two isocratic high performance liquid chromatography (HPLC) pumps 148 for generation of carrier flow (PN1130), a syringe pump (Kloehn v6) for controlling cross149 flow, a purging port (PN1610) for rinsing, a manual injection valve (Rheodyne 9725i), a 150 temperature controlled AF4 channel oven for sample fractionation (PN4020), preparative 151 flow cell for UV (PN3211-003), and a fraction collector (PN8050). AF4 operation and data 152 collection were carried out using Postnova AF2000 software. Separations were performed 153 at $22^{\circ} \mathrm{C}$ in a channel that contained a $350 \mu \mathrm{m}$ or a $250 \mu \mathrm{m}$ spacer. The channel had a tip154 to-tip length of $27.5 \mathrm{~cm}$, initial width $2.0 \mathrm{~cm}$, and final width of $0.5 \mathrm{~cm}$. A regenerated 155 cellulose (RC) membrane with molecular weight cut-off (MWCO) value of $100 \mathrm{kDa}(\mathrm{Z}$ MEM-AQU-529, Postnova) was used unless otherwise mentioned. The injection volume was $20-1000 \mu$ l. Prior to sample injection, aggregated material was removed by centrifugation (Eppendorf centrifuge 5415D, 10000 g, 5 min). The outlet flow was 159 monitored at 260 or $280 \mathrm{~nm}$ using an inline variable wavelength detector (Shimadzu SPD$16020 \mathrm{~A}$; Shimadzu, Kyoto, Japan) with detector range settings as appropriate for each input 161 sample concentration.

163 Standard viral buffer (see above 2.1) served as the AF4 mobile phase. $V_{\text {out }}$ was $0.2 \mathrm{ml} / \mathrm{min}$ 164 unless otherwise mentioned. Focusing was performed applying the same cross-flow that was used for fractionation. Focusing time varied from 10-30 min depending on the amount and the expected polydispersity of the injected sample. Between successive AF4 
$h=\frac{4 \pi \eta R_{g}}{\lambda} \sin \frac{\vartheta}{2}$

$186 \mathrm{P}$ hereby represents the scattering form factor describing the angular dependence of the 187 intensity of the scattered light, $\vartheta$ the observed angle, $\eta$ the refractive index of the solvent 188 medium and $\lambda$ the wavelength of the incident laser light. Based on the obtained radius of 189 gyration, the geometric diameter $\left(D_{g e o}\right)$ of icosahedral (spherical) virus particles was 
190

191 192 193 194 195 196 197 198 199 200 201 202 203 204 205 206 207 208 209 210 Protein concentration was measured by Bradford assay [41] using a microplate reader 211 (Thermo Scientific, Fair Lawn, NJ, USA) and bovine serum albumin (BSA) as a standard, 212 or by measuring $A_{260}$ and $A_{280}$ values (Eppendorf Photometer, Hamburg, Germany). The

\subsection{Monolithic chromatography}

Chromatographic experiments were carried out at room temperature using an ÄKTA Purifier 10 UPC (GE Healthcare, Uppsala, Sweden) liquid chromatography system operated by Unicorn 5.2 software (GE Healthcare, Uppsala, Sweden). A CIM-QA 1 mlmonolithic column (BIA Separations, Slovenia) was used for purification of PRD1 as previously described [11]. AF4 fractions containing the virus were pooled and centrifuged (Eppendorf centrifuge 5415D, 13000 rpm, $10 \mathrm{~min}$ ) prior to loading on the column.

Supernatant was injected using a $5 \mathrm{ml}$ loop. The chromatography was performed at a flow rate of $1 \mathrm{ml} / \mathrm{min}$ using the virus buffer (see 2.1). After sample loading, unbound material was removed by extensive washing with at least 20 column volumes or until the $A_{260}$ reached the baseline. Elution was performed with a linear $0-1.5 \mathrm{M} \mathrm{NaCl}$ gradient in 20 column volumes using the virus buffer supplemented with $2 \mathrm{M} \mathrm{NaCl}$. Columns were washed by raising the $\mathrm{NaCl}$ concentration to $2 \mathrm{M}$. The absorbance at $260 \mathrm{~nm}$ was continuously monitored and 0.5 or $1 \mathrm{ml}$ fractions were collected. Chromatography was repeated three times.

2.4 Assay of purified viruses: number of infectious viruses, protein amount, purity and yield 
213 number of infectious viruses (plaque forming units, PFU) was determined by plaque assay.

214 Recoveries (\%) were calculated from protein amount or PFU using the formulas:

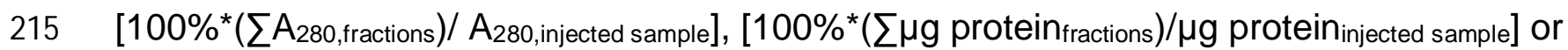

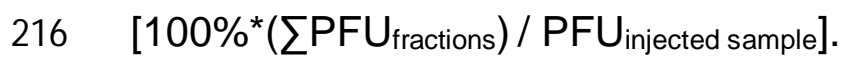

218 To assess protein content, AF4 fractions or viral input lysates were treated with $\sim 10 \%$ 219 trichloroacetic acid (TCA, v/v) on ice for $30 \mathrm{~min}$. The precipitated proteins were collected 220 by centrifugation (Eppendorf centrifuge 5415D, 13,000 rpm, $30 \mathrm{~min}, 4 \stackrel{\circ}{\mathrm{C}}$ ) and 221 resuspended in 1.5× SDS-PAGE sample buffer [42]. Boiled samples were analyzed in 222 SDS polyacrylamide (SDS-PAGE) gels made in-house that used $16 \%$ acrylamide in the 223 separation gels [42]. Proteins were visualized with Coomassie stain. Protein ladders 224 (\#26614 or \#26616, Thermo Scientific, Fair Lawn, NJ, USA) were used as size markers. 225 Gels were documented using ChemiDoc (Bio Rad, Hercules, USA).

\section{Results and discussion}

230 Detailed guides to design of AF4 protocols have been published [19, 43]. Adjustment of 231 several parameters is necessary for optimal separation and yield. These include flow rates 232 (focusing, channel, and cross-flow), focusing and elution times, the elution gradient profile 233 (constant, linear, exponential, or step-wise), ultrafiltration membrane (material and 234 MWCO), channel volume (spacer height, width, channel length), and mobile phase 235 composition (conductivity, pH, surfactants). Importantly, these parameters have 
236 interdependent effects on AF4 performance. Consequently, the selected AF4 operation 237 conditions are always compromises between separation, purity, dilution, and yield. We 238 performed a set of experiments with varying conditions and sample types to find the 239 optimal purification process for our model virus PRD1. Purity and infectivity of collected 240 fractions were monitored by measuring protein concentration and the number of infectious 241 viruses, and from that calculating the specific infectivity. Protein contents were visualized 242 in Coomassie-stained SDS-PAGE gels.

\subsubsection{Ultrafiltration membrane-virus interaction}

245 The RC membrane with a $10 \mathrm{kDa}$ MWCO is most commonly used for analysis of biological 246 macromolecules [44, 45]. Previous comparison of RC (10 kDa MWCO), triacetate 247 cellulose, and polyethersulphone membranes showed the highest recovery of negatively 248 charged VLPs with RC [46]. We chose instead the RC membrane with a $100 \mathrm{kDa}$ MWCO 249 to allow impurities less than $100 \mathrm{kDa}$ to pass through. RC has low isoelectronic point and 250 thus negative charge at neutral $\mathrm{pH}[47,48]$. Thus, the charge of sample components can 251 induce attractive or repulsive interactions leading to reduced recoveries and unexpected 252 elution behaviour. In addition, the pore density of membranes affects recoveries. High pore 253 density enables the entry of sample components to the pores and may reduce the 254 recoveries [49].

256 To test for the potential attractive or repulsive interactions with the $100 \mathrm{kDa}$ membrane, we 257 compared the UV signal intensities of fractograms obtained when 1XPRD1 samples were 258 eluted in the presence versus absence of cross-flow (Fig. S1A). In both cases, virus eluted 259 as a single sharp peak of similar intensity (Fig. S1B) and the sum of $A_{280}$ values of the 
260

261

262

263

264

265

peak regions were nearly identical with the input sample (Fig. S1C). This demonstrated that the virus particles were not significantly attracted to the membrane. This is in line with the successful purification of PRD1 using anion exchange columns [11,34] that suggested the binding of negatively charged regions of PRD1 virions to the anion exchange matrix. Since there was a significant difference in the retention times ( $\left.t_{r}\right)$ of runs performed in the presence versus absence of cross-flow, we concluded that repulsive forces between virions and the membrane were not strong enough to cause elution of the virus in the void. Due to their relatively large sizes, virions are usually well retained in the AF4 channel and elution at cross-flow rates close to zero is typical for channels with $350-380 \mu \mathrm{m}$ theoretical thickness $[26,27,29]$. PRD1 particles started eluting when the cross-flow had declined to $\sim 0.2 \mathrm{ml} / \mathrm{min}$ (Fig. S1B, see also Fig. 1B).

\subsubsection{Influence of focusing time}

Focusing time $\left(\mathrm{t}_{\mathrm{f}}\right)$ affects sample recovery, resolution, and analysis time. Too short a time results in incomplete equilibration and an increased mean layer thickness of the sample zone. As a result, sample components are eluted across a larger range of flow velocities which results in suboptimal resolution, band broadening, and potential elution in the void. An extended focusing period allows more time for potential attractive interactions between sample components, as well as between the sample and the membrane, which can induce sample aggregation and reduced recoveries $[21,50]$.

To optimise the $t_{f}$ for PEG-PRD1 samples, we tested 5, 10, and 15 min times combined with a $10 \mathrm{~min}$ linearly decaying cross flow gradient from $1 \mathrm{ml} / \mathrm{min}$ to $0.1 \mathrm{ml} / \mathrm{min}$ (Fig. $1 \mathrm{~A}$ ). In addition to virions, a PEG-PRD1 sample contains host-derived impurities that co- 
precipitate with virus particles during PEG-NaCl precipitation. Therefore, we expected to see a more complex fractogram compared to the single elution peak observed for partially purified 1xPRD1 (Fig. S1B). Here two peaks followed the void peak $\left(\mathrm{V}_{0}\right)$ : the first peak had low signal intensity, whereas the second displayed a $\mathrm{t}_{\mathrm{r}}$ of $\sim 18 \mathrm{~min}$ (Fig. 1B), a value close to that of 1xPRD1 ( 14 min in Fig. S1B). Increasing the $t_{f}$ from 5 to 10 or 15 min reduced the $V_{0}$, but did not have a significant effect on other peak intensities (Fig. 1B). A decreased $V_{0}$ usually results from better retention of small molecules [29]. Here, since molecules smaller than $100 \mathrm{kDa}$ passed through the accumulation wall, no changes in signal intensities of the first peak was detected. However, as the separation of the void peak from other peaks was slightly improved with longer $\mathrm{t}_{\mathrm{f}}, 10$ or 15 min were preferred for higher sample loads or with heterogeneous and polydisperse samples.

Pooled fractions representing both peaks were analyzed by denaturing SDS-PAGE gels (Fig. 1C). The first minor peak showed the presence of proteins ranging from high 200 $\mathrm{kDa}$ to low $\sim 12 \mathrm{kDa}$ molecular weights, whereas the second major peak was enriched with PRD1 specific proteins. The 37 genes in the PRD1 genome include 18 that encode protein components of mature virions [51]. They range in size from $\sim 5 \mathrm{kDa}$ (P20) to $\sim 64 \mathrm{kDa}$ (P2). Each virion contains 240 trimers of the $\sim 43 \mathrm{kDa}$ major coat protein (P3) [37, 51]. Consequently, this protein was visibly the most abundant protein species in the SDSPAGE gel for second peak (Fig. 1C). Hereafter, we refer the peak with $\mathrm{t}_{\mathrm{r}} \sim 18 \mathrm{~min}$ as the virus peak.

While many impurities were removed from the virus sample during AF4, some high molecular weight contaminants remained. Likewise, even though a $100 \mathrm{kDa}$ MWCO 
308

309

310

311

membrane was used, protein species smaller than $100 \mathrm{kDa}$ were observed in the first peak. This suggested that they were released from larger protein complexes during either AF4 or denaturing SDS-PAGE analysis. Control experiments using protein standards of $150,225,447$, and $669 \mathrm{kDa}$ revealed peak retention times of 4.3, 4.9, 5.6, and $6.8 \mathrm{~min}$, respectively (Fig. S2A), while a mixture of 225 and $447 \mathrm{kDa}$ proteins eluted as a single peak (Fig. S2B). Under the same elution conditions, the $t_{r}$ of the first peak in the PEGPRD1 fractogram was $\sim 8$ min. This confirmed that the first peak for PEG-PRD1 contained high molecular weight proteins and macromolecular complexes that could not be separated by the used AF4 analysis conditions.

\subsubsection{Effect of flow rates}

Cross-flow strength has the greatest impact on AF4 separation efficiency [21]. High $V_{c}$ improves separation, but at the cost of increased dilution and possible membrane interactions. High molecular weight analytes are more prone to dilution [50]. Experimental testing is required to determine the optimal $V_{c}$ for best separation and recovery. Virions are well retained in the channel and require rather slow $V_{c}$ for their fractionation [26, 27, 29]. For $1 \mathrm{xPRD} 1$ we tested linear 10 min gradients in which initial $\mathrm{V}_{\mathrm{c}}$ rates of $0.5,0.75,1.0$, or $1.5 \mathrm{ml} / \mathrm{min}$ were decreased to $0.1 \mathrm{ml} / \mathrm{min}$ (Fig. S3A). PRD1 particles eluted as a single peak in all cases. As expected, higher $V_{c}$ showed increased $t_{r}$ (Fig. S3B) due to sample components equilibrating in regions of lower laminar flow velocity closer to the accumulation wall [50]. The lowest $\mathrm{V}_{\mathrm{c}}$ resulted in the lowest peak intensity, whereas 1.0 and $1.5 \mathrm{ml} / \mathrm{min}$ rates resulted in comparable peak intensities (Fig. S3B). 
331 Comparison of two $\mathrm{V}_{\text {out }}$ rates $(0.2$ and $0.5 \mathrm{ml} / \mathrm{min})$ and two $\mathrm{V}_{\mathrm{c}}$ rates $(1.0$ and $1.5 \mathrm{ml} / \mathrm{min})$ on

332 separation of PEG-PRD1 sample components did not show significant change in

333 separation of the two peaks, in their signal intensities, or in recoveries of infectious viruses,

334 but higher $\mathrm{V}_{\text {out }}$ reduced the analysis time by $\sim 10 \mathrm{~min}$ (Fig. S4A-C). Finally we compared

335 the combination of flow rates that provided a $\mathrm{V}_{\mathrm{c}} / \mathrm{V}_{\text {out }}$ ratio of $\left.5: \mathrm{i}\right) \mathrm{V}_{\mathrm{c}}: 1.0 \mathrm{ml} / \mathrm{min}$ and $\mathrm{V}_{\text {out: }}$ :

$3360.2 \mathrm{ml} / \mathrm{min}$; ii) $\mathrm{V}_{\mathrm{c}}: 2.5 \mathrm{ml} / \mathrm{min}$ and $\mathrm{V}_{\text {out: }} 0.5 \mathrm{ml} / \mathrm{min}$; and iii) $\mathrm{V}_{\mathrm{c}}: 2.0 \mathrm{ml} / \mathrm{min}$ and $\mathrm{V}_{\text {out: }} 0.4$

$337 \mathrm{ml} / \mathrm{min}$. As expected, $\mathrm{t}_{\mathrm{r}}$ was approximately the same for all three combinations, while

338 increased flow rates did not improve resolution but reduced signal intensities (Fig. S4D).

\subsubsection{Influence of elution gradient type}

341 Our initial AF4 conditions did not result in baseline separation of the peaks for the PEG-

PRD1 sample, and also some high molecular weight complexes co-fractionated with the virions (Figs. 1). We investigated whether different step gradient types would improve the separation. The best resolution and consequent increase in specific infectivity correlated with longer elution time rather than with the gradient type (Fig. S5 and Fig. 2A). The absorbance measurements (Fig. 2B) and intensities of protein patterns in SDS-PAGE gels (Fig. 2C) correlated with the peak positions in the fractograms. Although the first peak eluted as a single peak, gel analysis of fractions 1-5 showed that it contained high molecular weight proteins and macromolecular complexes of various compositions eluting at different $\mathrm{V}_{\mathrm{c}}$ rates. In summary, many host protein contaminants were separated from the

351 virus fractions during AF4, but some high molecular weight impurities still co-fractionated with the virus (Fig. 2C, compare lanes 1-5 with lanes 6-8) that could be partially attributed

353 to the fact that virus eluted at the end of cross flow gradient. 
355 The two fractions from both the first and second peak having the highest $A_{280}$ values were 356 pooled (fractions 2-3 corresponding to 5-15 min, and fractions 6-7 corresponding to 25-35 357 min, respectively) and their virus and protein contents were assayed to evaluate the 358 biological activity of the virus, recovery yields, and purity (Table 1). Although the UV signal 359 did not reach the baseline between the peaks (Figs. 2A and 2B), the more than 1000-fold 360 difference in their virus contents indicated good separation (Table 1). The specific 361 infectivity of the virus was improved 7-fold compared to the analysed input PEG-PRD1 sample. Yields calculated from the infectious virus amounts indicated that $\sim 50 \%$ of the virus was recovered in those two pooled fractions 6 and 7 from the second peak. While higher yields could have been obtained by pooling more fractions, this would have increased the total volume and thereby decreased the virus concentration.

Total protein yields were significantly lower than that obtained for infectious viruses verifying that many host proteins were removed from the input sample through their passage through the $100 \mathrm{kDa}$ membrane (Table 1). Absorbance measurements at $280 \mathrm{~nm}$ reflect not only protein concentration, but also nucleic acids that absorb at $280 \mathrm{~nm}$ although their absorbance maximum is at $254 \mathrm{~nm}$. The Bradford assay is specific for proteins, but the reagent reacts preferentially with certain amino acid residues. Therefore, the observed differences in the recovery between these two assays was most probably due to variation in the nucleic acid and protein pools present in these fractions.

376 The higher $A_{260} / A_{280}$ ratio of the first peak relative to the virus peak suggested increased 377 nucleic acid concentration in the first peak (Fig. 2B). PEG-NaCl treatment is known to 378 precipitate not only proteins, but also DNA and ribosomes [7, 52]. Plant ribosomes 
analysed using similar AF4 elution conditions (i.e., linear cross flow gradient from $1 \mathrm{ml} / \mathrm{min}$ to $0 \mathrm{ml} / \mathrm{min}, \mathrm{V}_{\text {out }} 0.2 \mathrm{ml} / \mathrm{min}$ ) started to elute at a $\mathrm{V}_{\mathrm{c}}$ rate of $\sim 0.8 \mathrm{ml} / \mathrm{min}$ [53]. Since prokaryotic ribosomes ( 2.3 MDa) are 1.2 MDa smaller than eukaryotic ones [54], ribosomes present in PEG-PRD1 precipitates would be expected to start eluting at higher $V_{c}$ rates. Consequently, they should start eluting in the first peak. In denaturing conditions prokaryotic ribosomes dissociate to yield three rRNA species and 54 ribosomal proteins that are less than $50 \mathrm{kDa}$, which could account for some of the small protein species observed in SDS-PAGE gels (Fig. 2C). Pretreatment of PRD1 lysate with DNase I or RNase A prior to PEG-NaCl precipitation significantly reduced the intensity of the first peak, confirming that the first peak contained nucleic acids and/or nucleoprotein complexes (Fig. S6). In general, our AF4 analyses showed that the intensity of the first peak relative to the virus peak varied between different PEG-PRD1 sample preparations (compare Figs 1, 2, S2, S4 and S5).

\subsection{AF4 analysis of PRD1 lysates}

AF4 has been used to measure total virus particle counts from crude vaccines produced in infected embryonated chicken eggs and cell culture supernatants [28, 29]. This suggested that AF4 had the potential to provide easy and fast purification of PRD1 directly from lysates of infected host cell cultures. AF4 analysis of crude PRD1 lysates resulted in two peaks having similar retention times to those from PEG-PRD1 (Fig. 3A, see also Fig. 2A). The significantly higher intensity of the first peak relative to the second peak indicated the expected large quantity of impurities in the lysate (Figs. 3A and B). Virus-induced cell lysis releases the host cell contents including a cocktail of degrading enzymes (proteases, nucleases, lipases) into the culture media. Thus, the amount of host nucleic acids, proteins 
and macromolecular complexes present in the lysate will vary depending on the time of sampling and is expected to increase as the lysis proceeds and to decrease during storage due to degradation of sample components. This explained the variation in the ratio of the first and the second peak intensities among sample preparations (Figs. 3A, 4C, and S8C). Virus purity was verified by SDS-PAGE analysis of fractions (Fig. 3C). Importantly, AF4 fractionation recovered approximately half of the virus in the input sample while

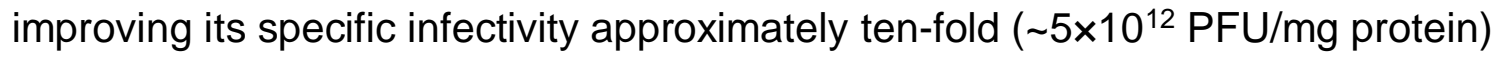
compared to the input lysate sample (Table 2). The only drawback was the relatively low virus concentration in the input lysate and further $\sim 7$-fold dilution that occurred during the fractionation process (Table 2). Consequently, due to low virus concentration in the input bacterial lysates, the amount of virus that could be produced by a single AF4 purification was low, $\sim 12 \mu \mathrm{g}$, unless several subsequent experiments were performed.

\subsection{AF4 as a tool to analyze virus infection}

Encouraged by the purification results obtained for PRD1 lysates, we tested whether AF4 could be used to monitor the progress of virus infection in terms of the release of infectious viruses. This is commonly done by classical one-step growth curve analysis, where virusinduced host cell lysis is detected as a decrease in the turbidity of the host cell culture (Fig. 4A). Lysis coincided with an increase in the number of infectious progeny viruses in the lysate that needs to be determined with a separate plaque assay. Here we used AF4 to analyze supernatants collected from non-infected (Fig. 4B) and infected cultures (Fig. 4C) at various times post infection (p.i.). Fractograms from non-infected cells and those from early time points (1 and 20 min p.i.) for the PRD1-infected culture did not differ significantly from the baseline obtained for LB growth medium (Figs. 4B and C, right $y$-axis), indicating 
427 that the amount of exported proteins and macromolecular complexes were below the 428 detection limit. The appearance of two peaks in the fractograms correlated with the onset 429 of virus-induced cell lysis that was visible at 115 min p.i. (Fig. 4A). Peaks increased in 430 intensity as lysis proceeded, but also the shapes of the peaks differed to some extent (Fig. 4314 C). The increasing number of free infectious viruses (Fig. 4D) correlated with the 432 increasing intensity of the second peak in the fractograms (Fig. 4C). Virus concentrations 433 in the first and second peak differed by approximately three orders of magnitude indicating 434 good separation (Fig. 4D). Approximately $30-40 \%$ of the infectious input virus was 435 recovered from the latest time point samples (115 and 185 min p.i.), but the concentration 436 of the recovered viruses were 2- to 3-fold lower than that of the input sample lysate (Fig. 437 4D).

439 Dilution during the fractionation can be decreased by using a thinner spacer [16, 50]. We 440 repeated the PRD1 one-step growth curve analysis using a $250 \mu \mathrm{m}$ spacer (Fig. S7) 441 instead of the $350 \mu \mathrm{m}$ one used previously. The virus peak eluted at $\mathrm{V}_{\mathrm{c}}$ of $\sim 0.5 \mathrm{ml} / \mathrm{min}$ 442 (Fig. S7C). Importantly, virus concentrations in the input sample and virus fractions from 443 later time points were similar (Fig. S7D) showing that careful timing of fraction collection 444 combined with reduced channel thickness can result in minimal sample dilution.

445 Furthermore, as the consequence of decrease in sample volume the specific infectivity 446 was improved two-fold. Overall, our results show that AF4 provides a rapid tool that can be 447 used to identify the optimal conditions for virus production. 
Since we intend to use AF4 to purify different viruses from samples having low, medium,

451 and high virus concentration, we tested the minimum and maximum sample loading 452 capacity consistent with good resolution and recovery. Our initial test included a series of ten-fold dilutions of the $1 \times$ PRD1 sample $\left(\sim 1.4 \times 10^{14} \mathrm{PFU} / \mathrm{ml}, 4 \times 10^{12} \mathrm{PFU} / \mathrm{mg}\right.$ protein).

Technical repetitions produced fractograms having similar intensities and shapes except for the lowest amount of $1 \times$ PRD1 tested (0.3 $\left.\mathrm{gg}, 1.4 \times 10^{9} \mathrm{PFUs}\right)$ (Fig. 5A). Higher sample loads increased the $t_{r}$ by one minute. Peak shapes remained regular up to $3 \mathrm{mg}$ of 1xPRD1, beyond which point the peaks broadened, acquired a tail, and started to show spikes. SDS-PAGE gel analysis of pooled virus peak fractions showed the expected pattern for PRD1 proteins (Fig. 5B). Further screening revealed that the detection limit for the preparative UV-cell was $\sim 1 \mu \mathrm{g}$ of $1 \mathrm{XPRD} 1$, which corresponded to $\sim 5 \times 10^{9}$ PFUs (data not shown). The previously reported detection limit for an analytical UV cell was $\sim 4 \times 10^{6}$ particles for influenza virus and $\sim 2 \mu \mathrm{g}$ of virions for Murine polyoma virus [27]. In summary, the linear working range was wide, from $1 \mu \mathrm{g}$ up to $\sim 3 \mathrm{mg}$, corresponding to $\sim 5 \times 10^{9}$ to $\sim 1 \times 10^{12}$ PFUs.

When virus recovery yields and specific infectivities were determined here for 1xPRD1 samples (Table 3) [11, 34, 40], even the highest input sample amounts tested showed good recovery of infectious viruses ( $60 \%$ to $~ 80 \%)$, whereas lower sample amounts reduced recovery yields. Separate comparison of the main peak and the tail region from a $3 \mathrm{mg}$ 1xPRD1 sample showed comparable specific infectivities of $6.8 \times 10^{12}$ and $3.3 \times 10^{12}$ PFU/mg protein, indicating that the tail region was not enriched with inactivated virus aggregates. That the fractionation did not significantly alter the specific infectivity of the input sample $\left(\sim 4 \times 10^{12} \mathrm{PFU} / \mathrm{mg}\right)$ indicated that samples from upstream purification steps might be better suited for purification by AF4. Therefore, the maximal loading capacity for 
475 PEG-PRD1 was also determined. Input samples of less than $\sim 1 \mathrm{mg}$ (corresponding to $\sim 8$

$476 \times 10^{11} \mathrm{PFUs}$ ) yielded fractogram peaks that were regular in shape (Figs. 1B, S4A),

477 whereas higher sample loads resulted in the characteristic virus peaks having spikes (see

478 Fig. 2A, S5B) and a broader tailed virus peak. As the concentration of infectious viruses in 479 lysates was $\sim 10-100$-fold lower than in PEG-PRD1 or 1 XPRD1, a maximum volume of $1 \mathrm{ml}$ 480 analysed here ( 2 $-4 \times 10^{11}$ PFUs) was efficiently separated (Figs. 3, 4, S4D, S6A, and $481 \mathrm{~S} 7 \mathrm{C})$.

482

\subsection{Particle size determination for PEG-PRD1}

484 To investigate the size distribution of particles present in the PEG-PRD1 samples, samples pretreated with DNase I were fractionated using an AF4 instrument equipped with MALS, RI, and UV detectors. To improve the separation of virus particles from any aggregates present in the PEG-PRD1 samples, the already established AF4 method was slightly modified by increasing the $\mathrm{V}_{\text {out }}$ rate to $0.5 \mathrm{ml} / \mathrm{min}$ and exponentially decreasing the $V_{c}$ at the end of elution. The resulting measurements showed good repeatability (Fig. 6A). The main peak monitored by UV at $260 \mathrm{~nm}$ eluted between $\sim 18-23 \mathrm{~min}$, followed by the elution of larger particles and aggregates starting from 28 to $\sim 60 \mathrm{~min}$. Measurement of infectious viruses from collected fractions confirmed the presence of viruses in the main peak. The measured intensity distribution profiles for the main peak showed an excellent agreement with the applied spherical model (Equation (1) (Fig. S8). By these means, not only a radius of gyration of $24.5 \pm 1.3 \mathrm{~nm}$ across the virus peak was determined indicating that the virus particles were homogeneous in size (Fig. 6B), but also the spherical

497 (icosahedral) shape of PRD1 particles could be confirmed (Fig. S8). Conversion of the obtained radius of gyration into a geometric diameter of $63.2 \pm 3.2 \mathrm{~nm}$ thereby showed 
499

500

501

good correlation with the previously reported dimensions of PRD1 [37]. The size distribution of the aggregates was determined via a random coil model (Fig. 6B). However, due to the lack of fitting of the experimental data to the random coil model or any other available models (data not shown), the presented sizes are only rough estimates.

\subsection{AF4 as the first step in tandem, ultracentrifugation-free virus purification protocol}

AF4 purification of viruses from complex mixtures of host-derived impurities had some drawbacks. First, some large protein complexes co-eluted with the virus, especially in the case of PEG-PRD1 samples (see Fig. 2). Second, maximizing virus recovery by pooling more fractions results in greater virus dilution due to increased total volume. Therefore, we included monolithic anion exchange chromatography as an additional downstream purification step to potentially remove the large impurities and to concentrate the sample.

The previously published protocol for monolithic chromatography purification of PRD1 [11] was followed here. For this tandem purification, PEG-precipitated sample was fractionated with $\mathrm{AF} 4$, and then all virus peak fractions were pooled and further purified using CIM QA monolithic columns. Chromatograms showed the presence of a minor peak $\left(A_{280}\right)$ followed by a main peak that eluted at $0.5 \mathrm{M} \mathrm{NaCl}($ Fig. $7 \mathrm{~A})$, the previously reported $\mathrm{NaCl}$ concentration for PRD1 elution [11]. Analysis of the protein content in SDS-PAGE gels confirmed that peak fractions contained virus proteins accompanied by relatively few impurities (Fig. 7B). Virus titers in the fractions were high $\left(1.4-5.5 \times 10^{12} \mathrm{PFU} / \mathrm{ml}\right)$ and correlated with total protein concentration (Fig. 7C). Consequently, the specific infectivity of virus fractions was improved $\sim 5$-fold compared to the AF4-purified input sample (Table 4), confirming the visual observation from Coomassie stained SDS-PAGE gels. Based on Bradford protein assays, $\sim 33 \%$ of the input protein was recovered, whereas plaque assays 
523 showed full recovery of the input virus (Table 4). Repeats of this tandem purification

524 consistently yielded $\sim 50 \%$ and $\sim 60 \%$ recovery of protein and virus, respectively.

525 Previously reported recoveries for various bacteriophages purified utilizing monolithic

526 chromatography vary between 35 and 100\% [11, 12]. A subsequent differential

527 ultracentrifugation followed by resuspension of the virus pellet to small amount of buffer

528 was utilized to remove the salt and to reduce the sample volume. Although this step

529 increased the virus and protein concentrations, there was no change in the specific

530 infectivity. Virus recovery averaged $\sim 40 \%$.

531

532 For comparison with AF4 and tandem AF4-monolithic chromatography protocol, we also

533 purified PRD1 using the traditional ultracentrifugation method [40], where PEG-PRD1 was

534 purified by sequential rate zonal and density gradient centrifugations in $5-20 \%$ and $20-70 \%$

535 sucrose gradients followed by differential centrifugation to remove sucrose and to

536 concentrate the sample - a procedure that takes two working days. The average virus

537 concentration of the purified 2xPRD1 sample was high $\left(\sim 1.8 \times 10^{14} \mathrm{PFU} / \mathrm{ml}\right)$, average yield

538 was $\sim 23 \%$, and specific infectivity was $\sim 1.9 \times 10^{13} \mathrm{PFU} / \mathrm{mg}$ protein (Fig. S9). The average

539 virus concentration of the $1 \times$ PRD1 sample was $\left.\sim 3.1 \times 10^{14} \mathrm{PFU} / \mathrm{ml}\right)$, average yield was

$540 \sim 31 \%$, and specific infectivity was $\sim 1.5 \times 10^{13} \mathrm{PFU} / \mathrm{mg}$ protein, respectively. Therefore, our

541 tandem AF4 and monolithic chromatography method yielded virus with comparable purity

542 with 2xPRD1 in a similar amount of time, whereas AF4 alone resulted in specific

543 infectivities approximately one order of magnitude lower with comparable purity with

544 1xPRD1 obtained from rate-zonal purification of PEG-PRD1 (Supplementary table 1).

\section{Conclusions}


547 We used the model bacteriophage PRD1 [33] to investigate the potential of AF4 for the 548 purification of complex and relatively large viruses. The complex PRD1 virion comprises a $549 \sim 66 \mathrm{~nm}$ diameter protein capsid that is decorated with 20 nm spikes, within which lies the 550 viral genome enclosed within a membrane [36-39]. Our studies demonstrated that AF4 is

551 well suited for production of PRD1 preparations that possess both high purity and

552 infectivity. The recovery yields varied from $\sim 40 \%$ upwards to full recovery. However,

553 increased yield often came at the cost of increased sample dilution and lower virus

554 concentration, whereas increased specific infectivity incurred some decrease in virus

555 recovery. The greatest increase in specific infectivity was observed when starting with the

556 least purified input materials, i.e., bacterial cell lysates. However, the specific infectivity

557 achieved for both the lysate and the PEG-precipitated virus approached to that reported

558 previously for PRD1 purified by rate-zonal ultracentrifugation (1xPRD1) [11, 40]. The use

559 of thinner $250 \mu \mathrm{m}$ spacer or the use of AF4 in conjunction with CIM anion chromatography

560 allowed us to counteract dilution taking place during AF4. Consequently, the combination

561 of AF4 and monolithic chromatography provides an effective method for large scale virus

562 purification and is applicable to other types of macromolecular complexes as well.

564 AF4 also proved to be a rapid tool to analyse the virus content released from the infected cells. These include optimization of the virus amount (MOI) used for infecting the host, selection of host producing the highest amount of viruses or producing the minimum

567 amount of contaminating host proteins that could interfere with the purification process,

568 finding the optimal growth conditions for maximal virus production, and determining the 569 best time for collecting the viruses for further purification. In addition, AF4 showed potential 570 to be used for studies on virus attachment on host cells as well as on the studies of virus 
exit from infected cells. Finally, AF4 provides a rapid tool to produce virus material from

lysates for initial biochemical and -physical characterisation of viruses.

\section{Acknowledgements}

575

The authors acknowledge the support of the employees and the use of experimental resources of Instruct. We thank Academy of Finland (funding grant 272853) and University of Helsinki for the support to EU ESFRI Instruct Centre for Virus Production (ICVIR) used in this study. This study was supported by Academy Professor (Academy of Finland) funding grants 283072 and 255342 (D.H.B.). Soile Storman, Helin Veskiväli, Hanna Seppälä, and Sari Korhonen are thanked for excellent technical assistance.

\section{References:}

[1] C.A. Suttle, M arine viruses-major players in the global ecosystem, Nat Rev M icrobiol. 5 (2007) 801-812. [2] R. Danovaro, C. Corinaldesi, A. Dell'anno, J.A. Fuhrman, J.J. Middelburg, R.T. Noble, C.A. Suttle, Marine viruses and global climate change, FEM S M icrobiol Rev. 35 (2011) 993-1034.

[3] F. Rohwer, R.V. Thurber, Viruses manipulate the marine environment, Nature. 459 (2009) 207-212. [4] V.R. Després, J.A. Huffman, S.M. Burrows, C. Hoose, A.S. Safatov, G. Buryak, ]. Fröhlich-Nowoisky, W. Elbert, M.O. Andreae, U. Pöschl, Primary biological aerosol particles in the atmosphere: a review, Tellus B. 64 (2012) 1-58.

[5] R.E. Anderson, W.J. Brazelton, J.A. Baross, The deep viriosphere: assessing the viral impact on microbial community dynamics in the deep subsurface, Rev Mineral Geochem. 75 (2013) 649-675.

[6] S. Srinivasiah, J. Bhavsar, K. Thapar, M. Liles, T. Schoenfeld, K.E. Wommack, Phages across the biosphere: contrasts of viruses in soil and aquatic environments, Res Microbiol. 159 (2008) 349-357.

[7] K.R. Yamamoto, B.M. Alberts, R. Benzinger, L. Lawhorne, G. Treiber, Rapid bacteriophage sedimentation in the presence of polyethylene glycol and its application to large-scale virus purification, Virology. 40 (1970) 734-744.

[8] L. Pedro, S.S. Soares, G.N. Ferreira, Purification of bionanoparticles, Chem Eng Technol. 31 (2008) 815825.

[9] M.W. Wolf, U. Reichl, Downstream processing of cell culture-derived virus particles, Expert Rev Vaccines. (2011).

[10] J.E. Lawrence, G.F. Steward, Purification of viruses by centrifugation, in: W.M.G. Wilhelm S.W., and Suttle C.A. (Ed.) M anual of Aquatic Viral Ecology. ASLO, American Society of Limnology and Oceanography, 2010, pp. 166-181.

[11] H.M. Oksanen, A. Domanska, D.H. Bamford, M onolithic ion exchange chromatographic methods for virus purification, Virology. 434 (2012) 271-277. 
[12] E.M. Adriaenssens, S.M . Lehman, K. Vandersteegen, D. Vandenheuvel, D.L. Philippe, A. Cornelissen, M .R. Clokie, A.J. García, M. De Proft, M. Maes, CIM ®monolithic anion-exchange chromatography as a useful alternative to $\mathrm{CsCl}$ gradient purification of bacteriophage particles, Virology. 434 (2012) 265-270. [13] A. Podgornik, S. Yamamoto, M. Peterka, N.L. Krajnc, Fast separation of large biomolecules using short monolithic columns, J Chromatogr B. 927 (2013) 80-89.

[14] N.S. Atanasova, H.M. Oksanen, D.H. Bamford, Haloviruses of archaea, bacteria, and eukaryotes, Curr Opin Microbiol. 25 (2015) 40-48.

[15] J.C. Giddings, F. Yang, M.N. M yers, Flow-field-flow fractionation: a versatile new separation method, Science. 193 (1976) 1244-1245.

[16] K.G. Wahlund, J.C. Giddings, Properties of an asymmetrical flow field-flow fractionation channel having one permeable wall, Anal Chem. 59 (1987) 1332-1339.

[17] A. Litzen, K.G. Wahlund, Zone broadening and dilution in rectangular and trapezoidal asymmetrical flow field-flow fractionation channels, Anal Chem. 63 (1991) 1001-1007.

[18] A. Litzen, Separation speed, retention, and dispersion in asymmetrical flow field-flow fractionation as functions of channel dimensions and flow rates, Anal Chem. 65 (1993) 461-470.

[19] J. Gigault, J.M. Pettibone, C. Schmitt, V.A. Hackley, Rational strategy for characterization of nanoscale particles by asymmetric-flow field flow fractionation: A tutorial, Anal Chim Acta. 809 (2014) 9-24.

[20] S.K. Ratanathanawongs, D.L. Williams, Field-flow fractionation of proteins, polysaccharides, synthetic polymers, and supramolecular assemblies, J Sep Sci. 29 (2006) 1720-1732.

[21] K.-G. Wahlund, Flow field-flow fractionation: critical overview, J Chromatogr A. 1287 (2013) 97-112.

[22] B. Roda, A. Zattoni, P. Reschiglian, M.H. Moon, M. M irasoli, E. Michelini, A. Roda, Field-flow fractionation in bioanalysis: a review of recent trends, Anal Chim Acta. 635 (2009) 132-143.

[23] F.A. M essaud, R.D. Sanderson, J.R. Runyon, T. Otte, H. Pasch, S.K.R. Williams, An overview on field-flow fractionation techniques and their applications in the separation and characterization of polymers, Prog Polym Sci. 34 (2009) 351-368.

[24] G. Yohannes, M. Jussila, K. Hartonen, M.-L. Riekkola, Asymmetrical flow field-flow fractionation technique for separation and characterization of biopolymers and bioparticles, J Chromatogr A. 1218 (2011) 4104-4116.

[25] M. Baalousha, B. Stolpe, J. Lead, Flow field-flow fractionation for the analysis and characterization of natural colloids and manufactured nanoparticles in environmental systems: a critical review, J Chromatogr A. 1218 (2011) 4078-4103.

[26] J.C. Giddings, F.J. Yang, M.N. M yers, Flow field-flow fractionation: new method for separating, purifying, and characterizing the diffusivity of viruses, J Virol. 21 (1977) 131-138.

[27] Y.P. Chuan, Y.Y. Fan, L. Lua, A.P. M iddelberg, Quantitative analysis of virus-like particle size and distribution by field-flow fractionation, Biotechnol Bioeng. 99 (2008) 1425-1433.

[28] T. Bousse, D.A. Shore, C.S. Goldsmith, M.J. Hossain, Y. Jang, C.T. Davis, R.O. Donis, J. Stevens, Quantitation of influenza virus using field flow fractionation and multi-angle light scattering for quantifying influenza A particles, J Virol M ethods. 193 (2013) 589-596.

[29] Z. Wei, M. M cevoy, V. Razinkov, A. Polozova, E. Li, J. Casas-Finet, G.I. Tous, P. Balu, A.A. Pan, H. Mehta, Biophysical characterization of influenza virus subpopulations using field flow fractionation and multiangle light scattering: correlation of particle counts, size distribution and infectivity, J Virol M ethods. 144 (2007) 122-132.

[30] D. Lipin, Y. Chuan, L. Lua, A. M iddelberg, Encapsulation of DNA and non-viral protein changes the structure of murine polyomavirus virus-like particles, Arch Virol. 153 (2008) 2027-2039.

[31] A. Citkowicz, H. Petry, R.N. Harkins, O. Ast, L. Cashion, C. Goldmann, P. Bringmann, K. Plummer, B. R. Larsen, Characterization of virus-like particle assembly for DNA delivery using asymmetrical flow field-flow fractionation and light scattering, Anal Biochem. 376 (2008) 163-172.

[32] R. Lang, G. Winter, L. Vogt, A. Zürcher, B. Dorigo, B. Schimmele, Rational design of a stable, freezedried virus-like particle-based vaccine formulation, Drug Dev Ind Pharm. 35 (2009) 83-97.

[33] R.H. Olsen, J.S. Siak, R.H. Gray, Characteristics of PRD1, a plasmid-dependent broad host range DNA bacteriophage, J Virol. 14 (1974) 689-699. 
[34] L. Walin, R. Tuma, G.J. Thomas, D.H. Bamford, Purification of viruses and macromolecular assemblies for structural investigations using a novel ion exchange method, Virology. 201 (1994) 1-7.

[35] D.H. Bamford, J.K. Bamford, S.A. Towse, G.J. Thomas, Jr., Structural study of the lipid-containing bacteriophage PRD1 and its capsid and DNA components by laser Raman spectroscopy, Biochemistry. 29 (1990) 5982-5987.

[36] N.G. Abrescia, J.M. Grimes, H.M. Kivelä, R. Assenberg, G.C. Sutton, S.J. Butcher, J.K. Bamford, D.H. Bamford, D.I. Stuart, Insights into virus evolution and membrane biogenesis from the structure of the marine lipid-containing bacteriophage PM2, M ol Cell. 31 (2008) 749-761.

[37] N.G. Abrescia, J.J. Cockburn, J.M . Grimes, G.C. Sutton, J.M. Diprose, S.J. Butcher, S.D. Fuller, C. San M artin, R.M. Burnett, D.I. Stuart, D.H. Bamford, J.K. Bamford, Insights into assembly from structural analysis of bacteriophage PRD1, Nature. 432 (2004) 68-74.

[38] ].J. Cockburn, N.G. Abrescia, J.M. Grimes, G.C. Sutton, J.M. Diprose, J.M. Benevides, G.J. Thomas, Jr., J.K. Bamford, D.H. Bamford, D.I. Stuart, M embrane structure and interactions with protein and DNA in bacteriophage PRD1, Nature. 432 (2004) 122-125.

[39] N.S. Atanasova, A. Sencilo, M .K. Pietilä, E. Roine, H.M. Oksanen, D.H. Bamford, Comparison of lipidcontaining bacterial and archaeal viruses, Adv. Vir. Res., 92 (2015) 1-61.

[40] ].K. Bamford, D.H. Bamford, Large-scale purification of membrane-containing bacteriophage PRD1 and its subviral particles, Virology. 181 (1991) 348-352.

[41] M.M. Bradford, A rapid and sensitive method for the quantitation of microgram quantities of protein utilizing the principle of protein-dye binding, Anal Biochem. 72 (1976) 248-254.

[42] V.M. Olkkonen, D.H. Bamford, Quantitation of the adsorption and penetration stages of bacteriophage \$6 infection, Virology. 171 (1989) 229-238.

[43] Z. Kuklenyik, M.S. Gardner, B.A. Parks, D.M. Schieltz, J.C. Rees, L.G. M cWilliams, Y.M. Williamson, J.L. Pirkle, J.R. Barr, Multivariate DoE optimization of asymmetric flow field flow fractionation coupled to quantitative LC-M S/M S for analysis of lipoprotein subclasses, Chromatography. 2 (2015) 96-117.

[44] M. Wagner, C. Pietsch, L. Tauhardt, A. Schallon, U.S. Schubert, Characterization of cationic polymers by asymmetric flow field-flow fractionation and multi-angle light scattering-a comparison with traditional techniques, J Chromatogr A. 1325 (2014) 195-203.

[45] U.B. Kavurt, M. Marioli, W.T. Kok, D. Stamatialis, M embranes for separation of biomacromolecules and bioparticles via flow field-flow fractionation, J Chem Technol Biotechnol. 90 (2015) 11-18.

[46] R. Lang, L. Vogt, A. Zürcher, G. Winter, Asymmetrical flow FFF as an analytical tool for the investigation of the physical stability of virus-like particles, LC GC North America. 27 (2009) 844-852.

[47] N. Bendixen, S. Losert, C. Adlhart, M. Lattuada, A. Ulrich, M embrane-particle interactions in an asymmetric flow field flow fractionation channel studied with titanium dioxide nanoparticles, J Chromatogr A. 1334 (2014) 92-100.

[48] M. Pontié, Effect of aging on UF membranes by a streaming potential (SP) method, Journal of membrane science. 154 (1999) 213-220.

[49] J. Ashby, S. Schachermeyer, Y. Duan, L.A. Jimenez, W. Zhong, Probing and quantifying DNA-protein interactions with asymmetrical flow field-flow fractionation, J Chromatogr A. 1358 (2014) 217-224.

[50] R.N. Qureshi, W.T. Kok, Optimization of asymmetrical flow field-flow fractionation (AF4), LC GC Europe. $23(2010) 5$.

[51] H. Oksanen, D. Bamford, Family Tectiviridae, in: M.J. Andrew M.Q. King, E.B.C. Adams, and Elliot ]. Lefkowitz (Eds.) Virus Taxonomy. , Academic Press: London, UK, 2012, pp. 317-321.

[52] ].T. Lis, R. Schleif, Size fractionation of double-stranded DNA by precipitation with polyethylene glycol, Nucleic Acids Res. 2 (1975) 383-390.

[53] L. Pitkänen, P. Tuomainen, K. Eskelin, Analysis of plant ribosomes with asymmetric flow field-flow fractionation, Anal Bioanal Chem. 406 (2014) 1629-1637.

[54] S. M elnikov, A. Ben-Shem, N.G. de Loubresse, L. Jenner, G. Yusupova, M. Yusupov, One core, two shells: bacterial and eukaryotic ribosomes, Nature Structural \& M olecular Biology. 19 (2012) 560-567. 
707 Figure 1. Effect of focusing time on resolution and recovery.

708 A) AF4 elution programmes with varying focusing times ( $\left.t_{f}\right)$.

B) Representative fractograms for PEG-PRD1 samples ( 5 $\times 10^{11}$ PFUs) with varying $t_{f}\left(t_{f}\right.$ was deducted from the time scale). Inset: void $\left(\mathrm{V}_{0}\right)$ and first minor peaks. $\mathrm{V}_{0}$ eluted at $\sim 1.8$ 711 min. Signal intensity $(V)$ was measured with UV-detector at $260 \mathrm{~nm}$ and 0.01 range setting.

C) Protein composition of the first and second peak ( $10 \mu \mathrm{g})$ compared to the same amount of PEG-PRD1 input sample and 1XPRD1 in a SDS-PAGE gel. Positions of standard proteins 714 (M) and major PRD1 proteins are shown.

Figure 2. AF4 fractionation of PEG-PRD1.

A) Representative fractogram from AF4 analysis of a PEG-PRD1 sample $\left(\sim 8 \times 10^{11}\right.$ PFUs $)$,

$t_{f}(15 \mathrm{~min})$ was deducted from the fractograms. Elution program is shown on the right $y$-axis (dashed red). UV-detector monitored UV-signal at $260 \mathrm{~nm}$ in volts (V) with a range setting of 0.01 (black solid line, left $y$-axis). $V_{0}$ is the void.

B) Absorbance measurements of fractions ( $1 \mathrm{ml}, 5 \mathrm{~min}$ each). The two fractions having the highest absorbance values in the first and second peak are boxed.

C) SDS-PAGE gel analysis of fractions 1-12 compared to $10 \mu \mathrm{g}$ of the AF4 input sample PEG-PRD1, and $10 \mu \mathrm{g}$ of $1 \mathrm{xPRD} 1$ used as purification control. Proteins were visualized with

Figure 3. AF4 analysis of PRD1 lysate. 
728 A) Representative fractogram from AF4 analysis of a PRD1 lysate sample (1 ml) containing $729 \sim 1.0 \times 10^{11}$ PFUs. UV-detector monitored UV signal at $260 \mathrm{~nm}$ in volts (V) with a 0.001 range 730 setting (blue line, left $y$-axis). Elution program is shown on the right $y$-axis (dashed red), $t_{f}$ 731 (15 min) was deducted from the time scale. $V_{0}$ is the void.

B) Absorbance measurements of fractions ( $1 \mathrm{ml}, 5 \mathrm{~min}$ each) from the beginning of elution.

C) SDS-PAGE gels of pooled fractions representing the first and second peaks (marked with 734 boxes in B), $\sim 10 \mu \mathrm{g}$ of 1xPRD1 as a purification control, and $\sim 10 \mu \mathrm{g}$ of PRD1 lysate (input 735 sample). Proteins were visualized with Coomassie stain. Positions of standard proteins (M) and major PRD1 proteins are shown.

Figure 4. AF4 analysis of PRD1 infection: one-step growth curve.

739

740

A) Virus life cycle. Turbidity of PRD1 infected (blue) and uninfected cultures (red, dashed) was monitored at $\mathrm{OD}_{550}$. At time zero $\left(\mathrm{OD}_{550} \sim 0.8\right)$, cells were infected using a $\mathrm{MOI}$ of 10 . At 20 min p.i., cells were washed to remove unadsorbed viruses. Since the infection was slow during the $50 \mathrm{~min}$ washing procedure at room temperature, those 50 min were deducted when displaying time on the $x$-axis. Coloured arrows indicate the time points analysed by AF4.

B) Representative fractograms from analysis of culture supernatants $(1 \mathrm{ml})$ collected at various time points from non-infected control cells. LB (Luria-Bertani media) control: the background signal from the growth media. UV-detector monitored UV signal at $260 \mathrm{~nm}$ in volts (V) with a 0.001 range setting (left y-axis). Elution program is shown on the right $y$-axis (dashed black). $V_{0}$ is the void. 
C) Representative fractograms from analysis of culture supernatants $(1.0 \mathrm{ml})$ collected at

751 various time points (min p.i.) from infected cells: 1 and 20 min p.i. (right y-axis); 115 and 185

752 min p.i. (left y-axis). AF4 running conditions were the same as in B). Fractions (0.8 ml) were

753 collected from the start of elution. $V_{0}$ is the void.

754

D) Two fractions with the highest $A_{280}$ values from the first (19-23 min) and second (35-43

755

min) peaks were pooled and their virus concentration (PFU/ml) assayed and compared to the input sample. Error bars: standard deviation from three AF4 runs.

757

758

Figure 5. Sensitivity and maximal loading of PRD1.

A) AF4 analysis of 1xPRD1 samples: $8.8 \mathrm{mg}\left(\sim 3.4 \times 10^{13}\right.$ PFUs $)$ and a series of ten-fold dilutions from $3.3 \mathrm{mg}$ to $\sim 0.3 \mu \mathrm{g}\left(1.4 \times 10^{13}\right.$ to $\left.\sim 1.4 \times 10^{9} \mathrm{PFU}\right)$. The $15 \mathrm{~min}$ focusing step was followed by a $10 \mathrm{~min}$ linear ramp from $1 \mathrm{ml} / \mathrm{min}$ to $0 \mathrm{ml} / \mathrm{min}$, $\mathrm{t}_{\mathrm{f}}$ was subtracted from the time scale (x-axis). Injection volume was 0.1 or $0.5 \mathrm{ml}$.

B) SDS-PAGE gels of pooled fractions of the virus peak, fractions preceding the virus peak, and $\sim 6 \mu \mathrm{g}$ of 1xPRD1 input sample. Proteins were visualized with Coomassie stain.

Figure 6. Particle size determination of PEG-PRD1.

A) Fractograms of two independent AF4 analyses of PEG-PRD1 ( $3 \times 10^{10}$ PFUs). Samples were pretreated with DNase I. UV-detector monitored UV signal at $260 \mathrm{~nm}$ in volts (V) with a 0.001 range setting (solid lines, left y-axis). The elution program (dashed line, right y-axis)

770 included a 25 min linear elution gradient that was followed by exponential decrease to 0.08 $771 \mathrm{ml} / \mathrm{min}$; $V_{\text {out }}$ was $0.5 \mathrm{ml} / \mathrm{min} . \mathrm{V}_{0}$ is the void. 
B) Light scattering signal $\left(\mathrm{LS}^{\circ} 0^{\circ}\right)$ and size distribution $\left(\mathrm{R}_{\mathrm{g}}\right)$ of PEG-PRD1 sample 774 components. The inset shows the size distribution of virus particles in the peak eluting 775 between 18-23 min. $R_{g}$ values were determined using a sphere model for the virus peak and 776 a random coil model for molecules eluting from $~ 28$ min onwards.

Figure 7. Tandem purification of PEG-PRD1 with AF4 and CIM anion exchange 779 chromatography.

780 A) Representative elugram of monolithic chromatography analysis. PEG-PRD1 was first 781 fractionated by AF4, then pooled viral fractions ( $\left.3.4 \times 10^{12} \mathrm{PFU}, 1.4 \mathrm{mg}\right)$ were applied to 782 CIM 1-ml-QA column in $20 \mathrm{mM}$ potassium phosphate $\mathrm{pH} 7.2,1 \mathrm{mM} \mathrm{MgCl}$. Elution was 783 performed using buffer supplemented with $2 \mathrm{M} \mathrm{NaCl}$ using a linear 0-1.5 M NaCl gradient 784 and flow rate of $1 \mathrm{ml} / \mathrm{min} . \mathrm{A}_{280}$ values and $\mathrm{NaCl}$ concentration of the elution gradient are 785 shown. $0.5 \mathrm{ml}$ fractions were collected.

B) SDS-PAGE gels of fractions 25-33. Proteins were visualized with Coomassie stain. M:

787 protein standards; the most abundant PRD1 virion proteins are marked on the right.

C) Protein concentration of fractions 22-35 and concentration of infectious viruses in 789 fractions 25-35. Protein content of fractions marked with asterisks was below the 790 detection limit $(1.0 \mu \mathrm{g}, 0.01 \mu \mathrm{g} / \mu \mathrm{l})$; virus concentration of fraction 25 was below $1 \times 10^{8}$ $791 \mathrm{PFU} / \mathrm{ml}$. 
Table 1. Purification of PEG-PRD1 by AF4.

\begin{tabular}{lccc} 
& Input & peak 1 & peak2 \\
\hline Volume $(\mathrm{ml})$ & 0.5 & 2.0 & 2.0 \\
PFU/ml & $1.5 \mathrm{E}+12$ & $6.6 \mathrm{E}+07$ & $1.8 \mathrm{E}+11$ \\
PFUs & $7.6 \mathrm{E}+11$ & $1.3 \mathrm{E}+08$ & $3.7 \mathrm{E}+11$ \\
PFU yield $(\%)$ & 100 & 0.02 & 49 \\
Protein $(\mu \mathrm{g} / \mathrm{ml})$ & 2333 & 37 & 37 \\
Protein $(\mu \mathrm{g})$ & 1166 & 75 & 74 \\
Protein yield $(\%)$ & 100 & 6.4 & 6.3 \\
PFU/mg protein & $6.5 \mathrm{E}+08$ & $1.8 \mathrm{E}+09$ & $4.9 \mathrm{E}+12$ \\
$\mathrm{~A}_{280} / \mathrm{ml}$ & 12.8 & 0.52 & 0.46 \\
$\mathrm{~A}_{280}$ units & 6.4 & 1.04 & 0.91 \\
$\mathrm{~A}_{280}$ yield $(\%)$ & 100 & 16 & 14 \\
PFU/A & $1.2 \mathrm{E}+11$ & $1.3 \mathrm{E}+08$ & $4.0 \mathrm{E}+11$ \\
\hline
\end{tabular}


Table 2. Purification of PRD1 lysate by AF4.

\begin{tabular}{|c|c|c|c|}
\hline & Input & peak 1 & peak 2 \\
\hline Volume (ml) & 0.5 & 2.0 & 2.0 \\
\hline $\mathrm{PFU} / \mathrm{ml}$ & $1.9 \mathrm{E}+11$ & $8.5 E+06$ & $2.8 \mathrm{E}+10$ \\
\hline PFUs & $9.5 E+10$ & $1.7 \mathrm{E}+07$ & $5.5 E+10$ \\
\hline PFU yield (\%) & 100 & 0.02 & 58 \\
\hline Protein $(\mu \mathrm{g} / \mu \mathrm{l})$ & 0.46 & 0.015 & 0.006 \\
\hline Protein $(\mu \mathrm{g})$ & 231 & 30.8 & 11.6 \\
\hline Protein yield (\%) & 100 & 13 & 5 \\
\hline $\mathrm{PFU} / \mathrm{mg}$ protein & $4.1 \mathrm{E}+11$ & $5.5 \mathrm{E}+08$ & $4.8 \mathrm{E}+12$ \\
\hline $\mathrm{A}_{280} / \mathrm{ml}$ & n.d. & 0.16 & 0.06 \\
\hline$A_{280}$ units & n.d. & 0.32 & 0.12 \\
\hline $\mathrm{PFU} / \mathrm{A}_{280}$ & n.d. & $5.4 \mathrm{E}+07$ & $4.8 \mathrm{E}+11$ \\
\hline \multicolumn{4}{|c|}{ n.d., not determined due to high absorbance values } \\
\hline
\end{tabular}


Table 3. Minimal and maximal loading capacity for 1xPRD1. Protein and virus content of pooled virus peaks were measured to monitor virus yield and purity, and for comparison with the input sample $\left(\sim 1.4 \times 10^{14} \mathrm{PFU} / \mathrm{ml}, 33 \mathrm{mg} / \mathrm{ml}, 4.1 \times 10^{12} \mathrm{PFU} / \mathrm{mg}\right.$ of protein).

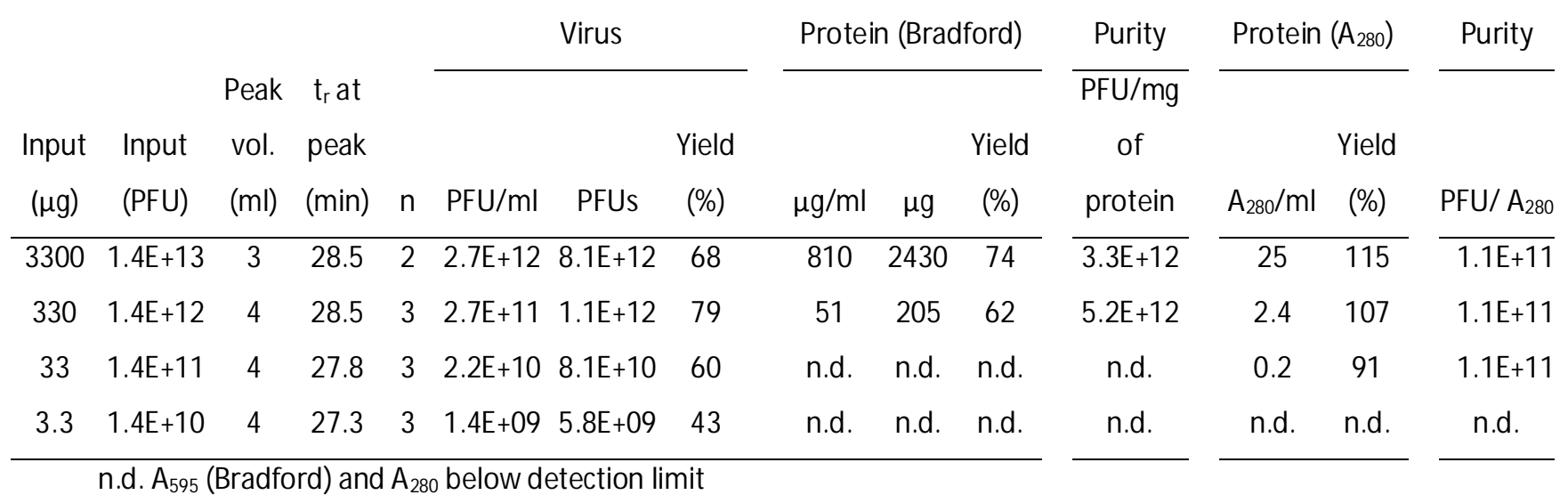


Table 4. Tandem AF4 - monolithic chromatographic purification of PEG-PRD1.

\begin{tabular}{|c|c|c|c|}
\hline & \multirow[t]{2}{*}{ AF4 Input } & \multirow{2}{*}{$\begin{array}{l}\text { AF4 output, CIM } \\
\text { Input }\end{array}$} & \multirow[b]{2}{*}{ CIM Output } \\
\hline & & & \\
\hline Volume (ml) & 1.0 & 5.0 & 2.0 \\
\hline Average virus conc. (PFU/ml) & $2.2 \mathrm{E}+13$ & $6.8 \mathrm{E}+11$ & $3.1 \mathrm{E}+12$ \\
\hline M aximum virus conc. (PFU/ml) & - & - & $5.5 \mathrm{E}+12$ \\
\hline Total virus amount (PFU) & $2.2 \mathrm{E}+13$ & $3.4 \mathrm{E}+12$ & $6.2 \mathrm{E}+12$ \\
\hline Virus yield (PFU, \%) & $100 \%$ & $15 \%$ & - \\
\hline Virus yield (PFU, \%) & & $100 \%$ & $182 \%$ \\
\hline Average protein conc. (mg/ml) & 3.6 & 0.29 & 0.25 \\
\hline M aximum protein conc. (mg/ml) & - & - & 0.46 \\
\hline Total protein amount (mg) & 3.6 & 1.5 & 0.50 \\
\hline Protein yield (mg, \%) & 100 & 42 & \\
\hline Protein yield (mg, \%) & & 100 & 33 \\
\hline Average specific infectivity (PFU/mg of protein) & $6.1 \mathrm{E} 11$ & $2.3 \mathrm{E}+12$ & $1.2 \mathrm{E}+13$ \\
\hline Average protein conc. $\left(A_{280} / \mathrm{ml}\right)$ & 30.0 & 2.1 & 2.5 \\
\hline Maximum protein conc. $\left(\mathrm{A}_{280} / \mathrm{ml}\right)$ & - & - & 4.3 \\
\hline Total protein amount ( $A_{280}$ units) & 30.0 & 10.6 & 5.0 \\
\hline Protein yield $\left(A_{280}, \%\right)$ & 100 & 35 & \\
\hline Protein yield $\left(\mathrm{A}_{280}, \%\right)$ & & 100 & 47 \\
\hline Average specific infectivity (PFU/A $A_{280}$ of protein) & & $3.2 E+11$ & $1.2 \mathrm{E}+12$ \\
\hline
\end{tabular}




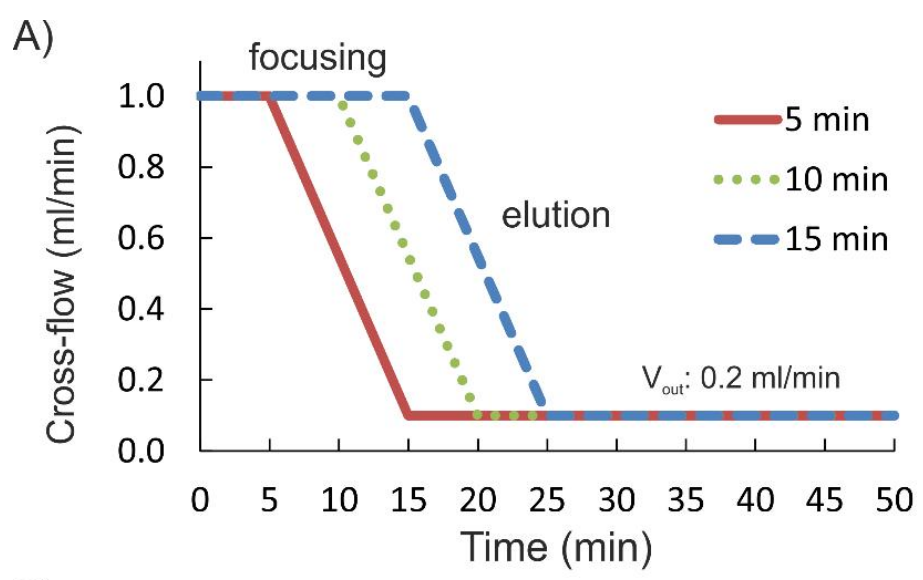

B)

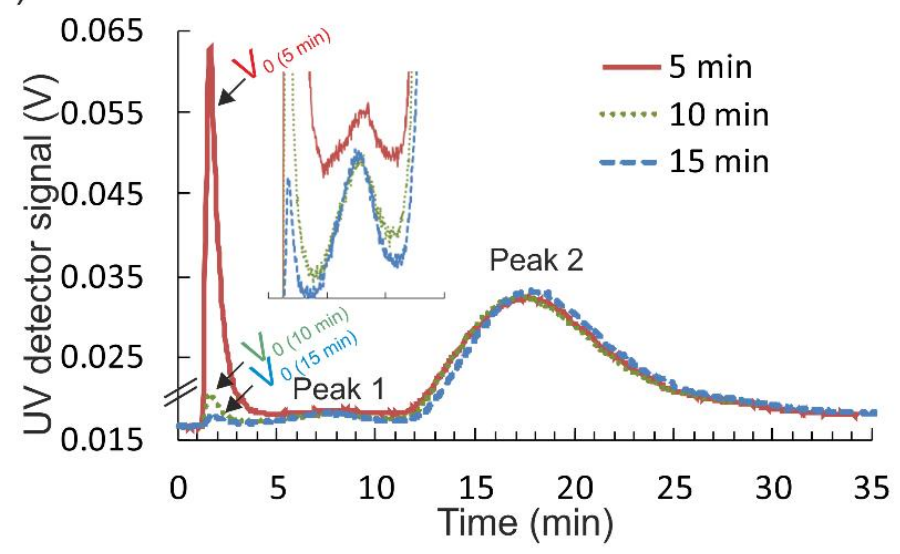

C)

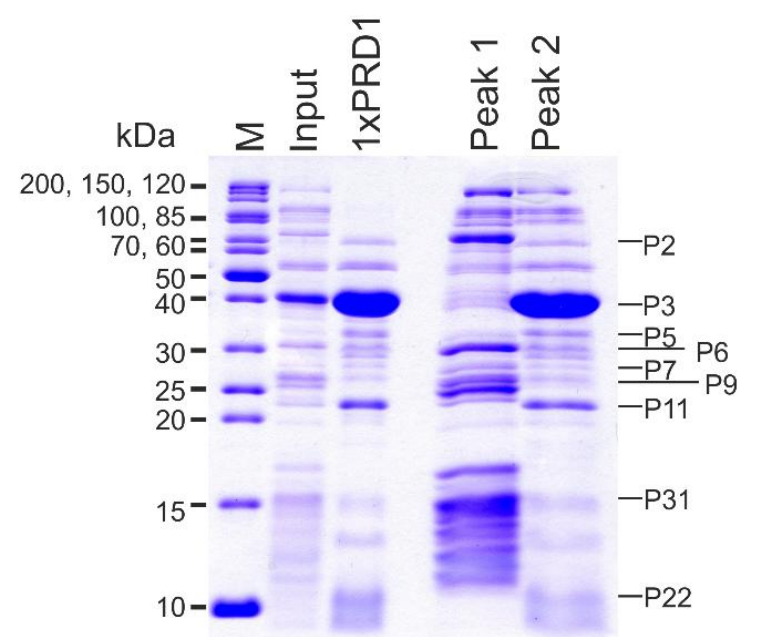

Fig 1. 
A)

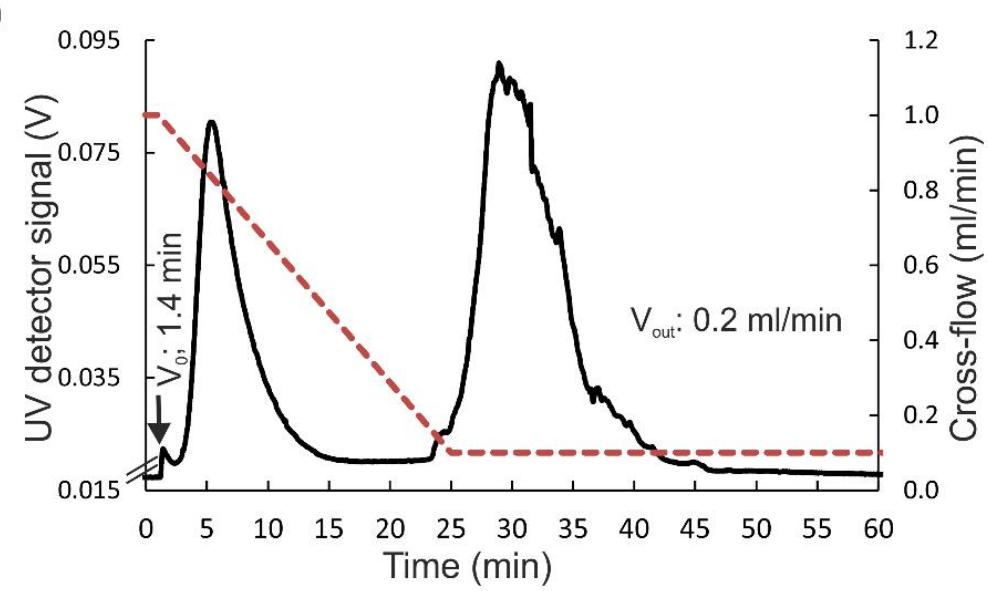

B)

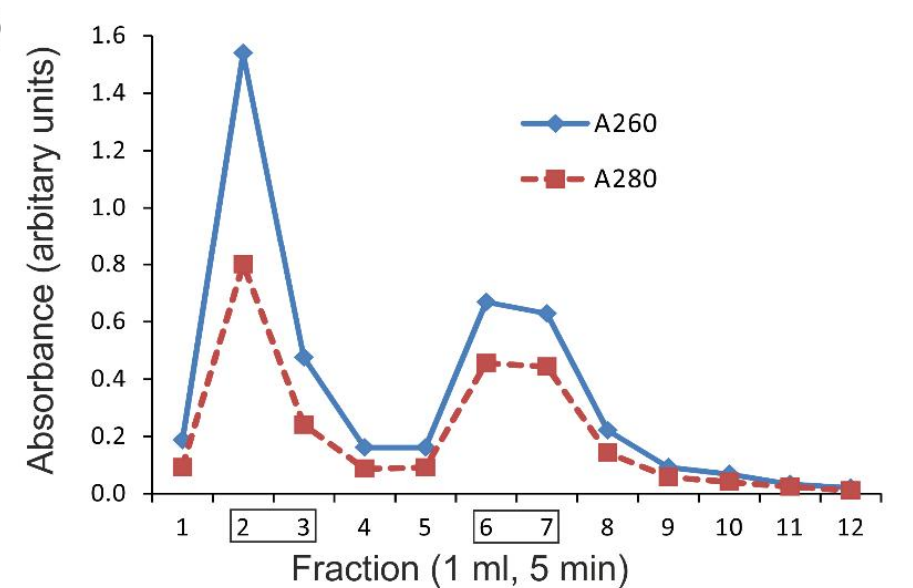

C) \begin{tabular}{ccccccccccccc}
\multicolumn{10}{c}{ Fraction (1 ml, $5 \mathrm{~min})$} \\
$\mathrm{kDa}$ \\
200,
\end{tabular}

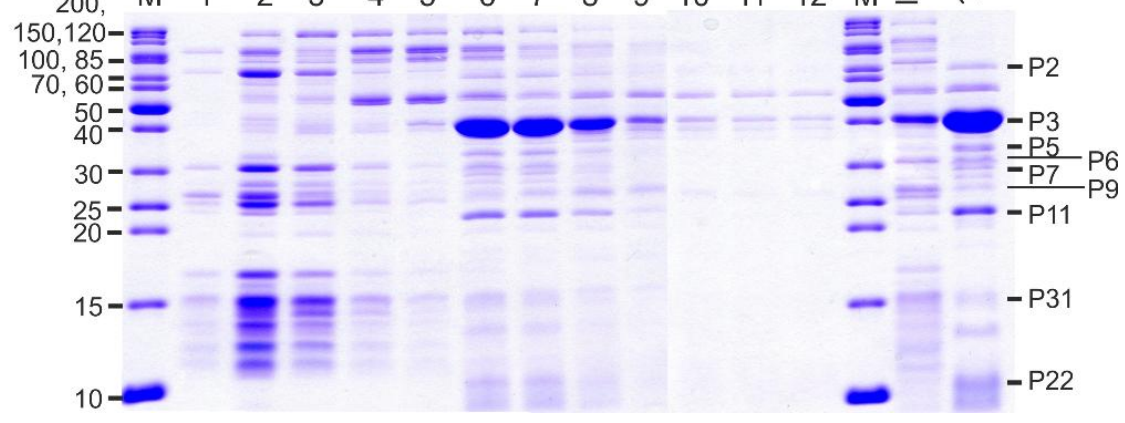

Fig. 2. 
A)

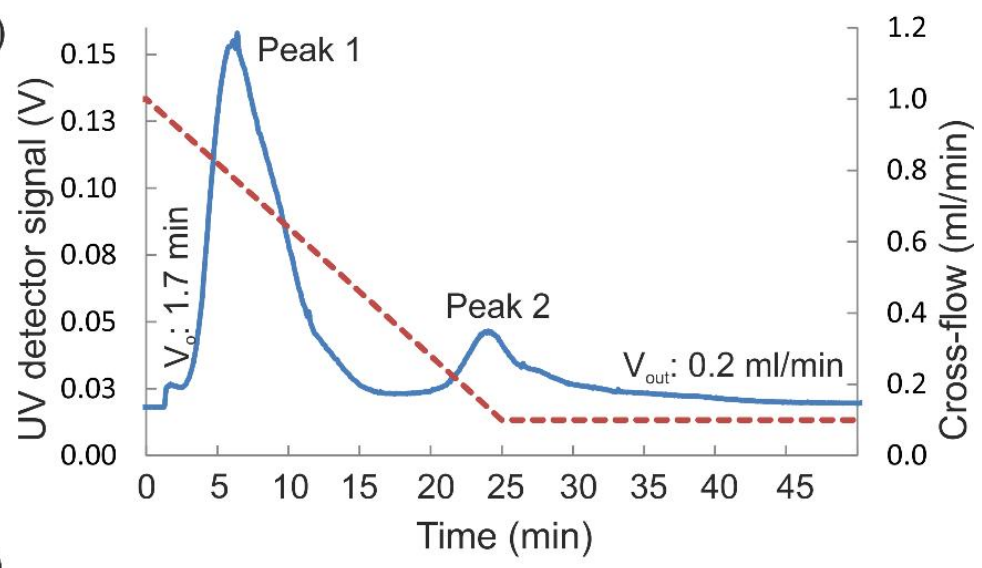

B)

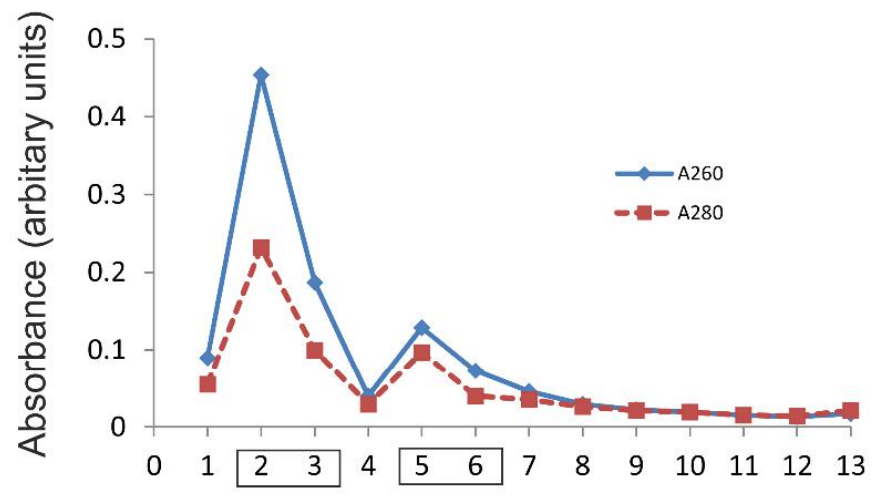

Fraction (1 ml, $5 \mathrm{~min}$ )

C)

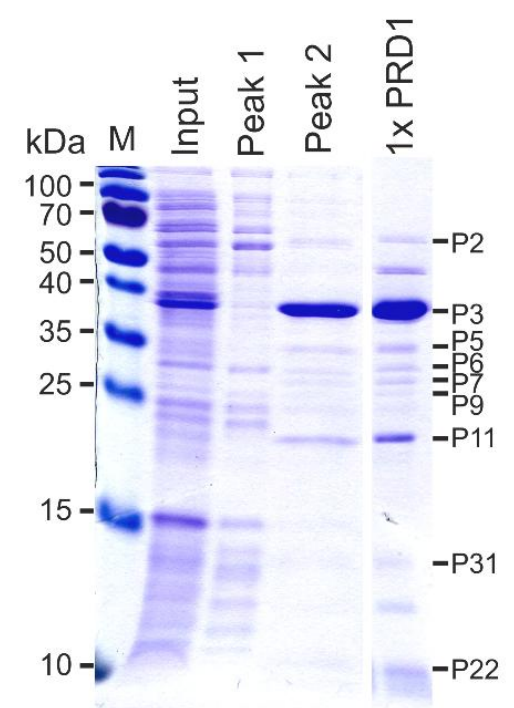

Fig. 3. 
A)

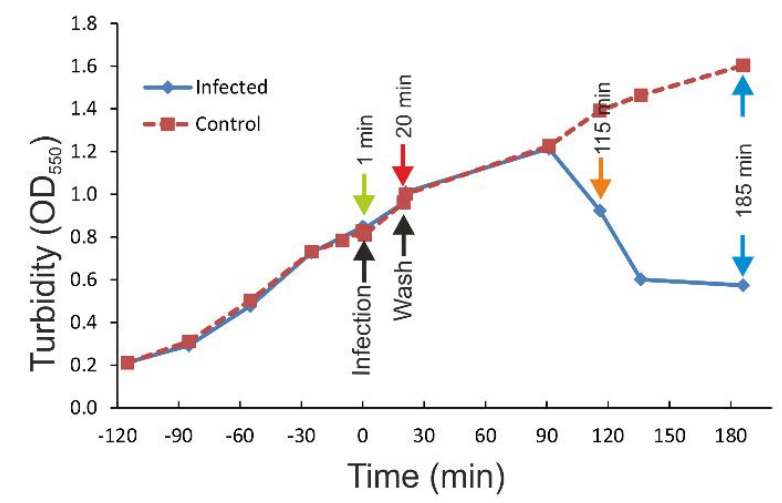

C)

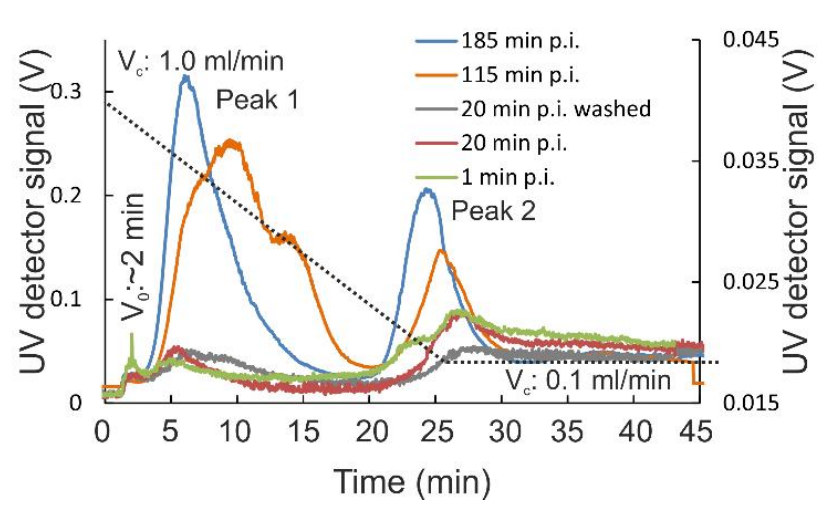

B)

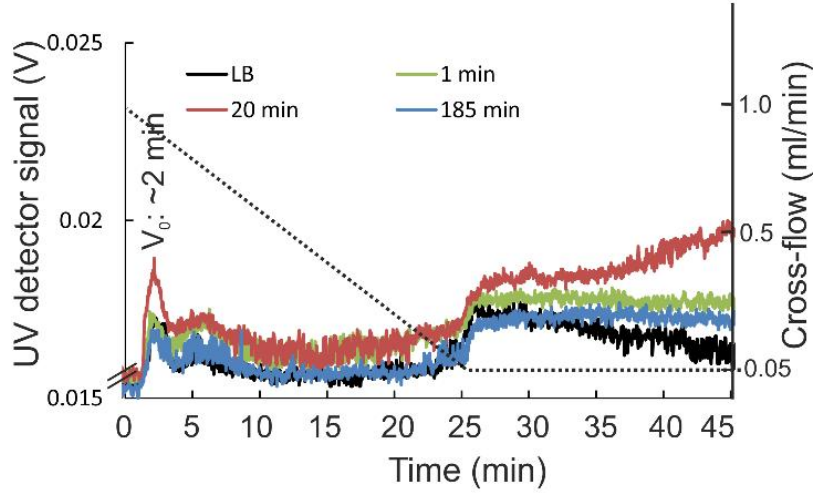

D)

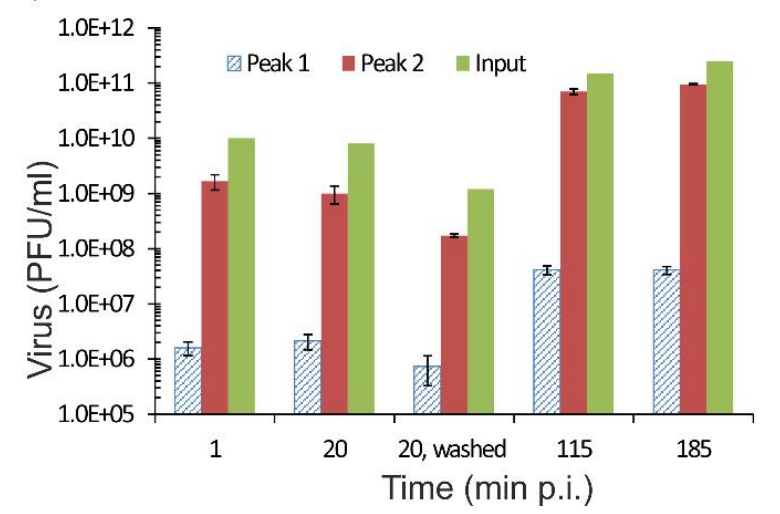

Fig. 4. 
A)
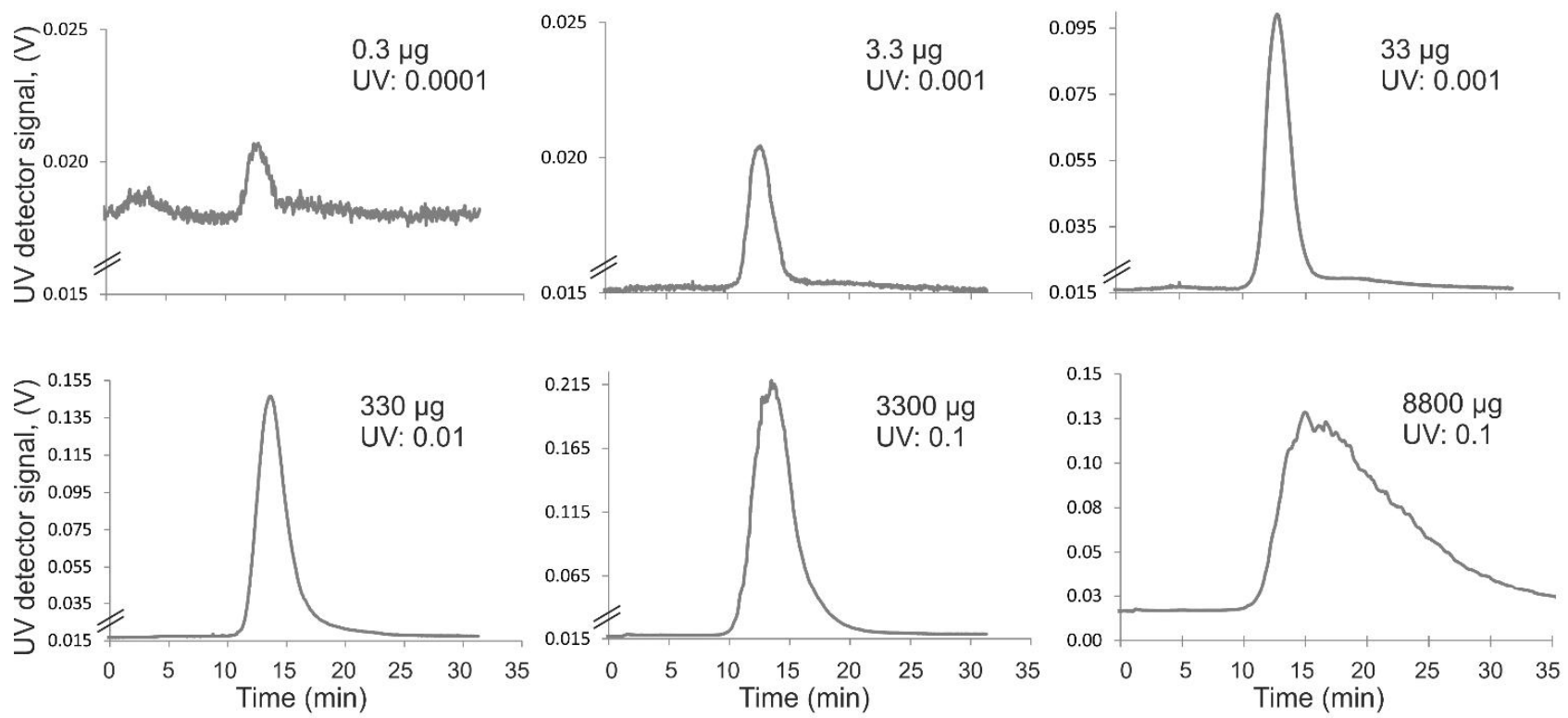

B)

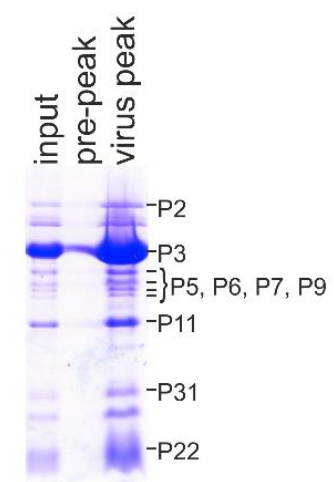

Fig. 5. 
A)

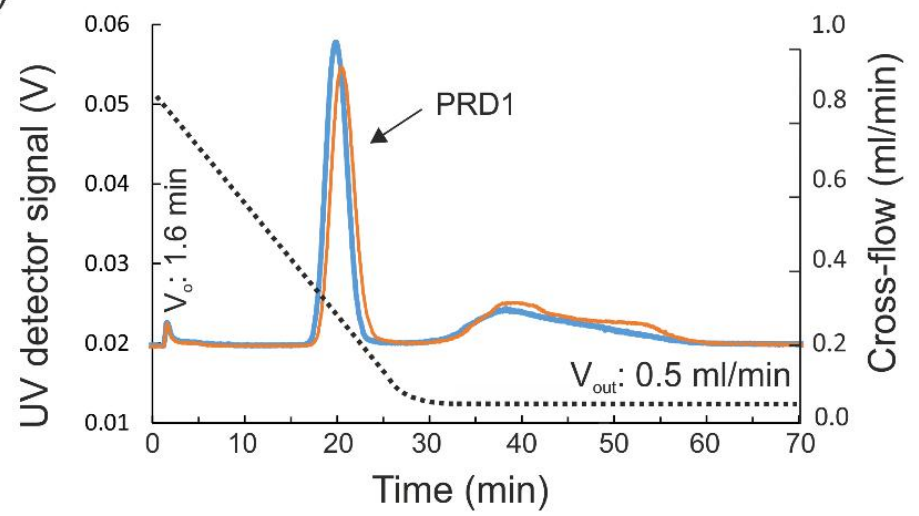

B)

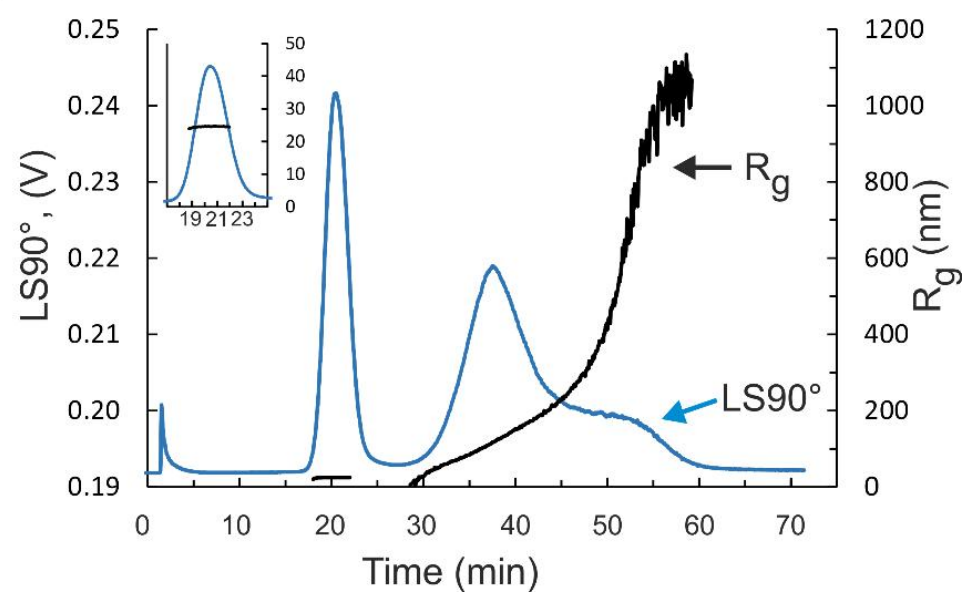

Fig. 6. 


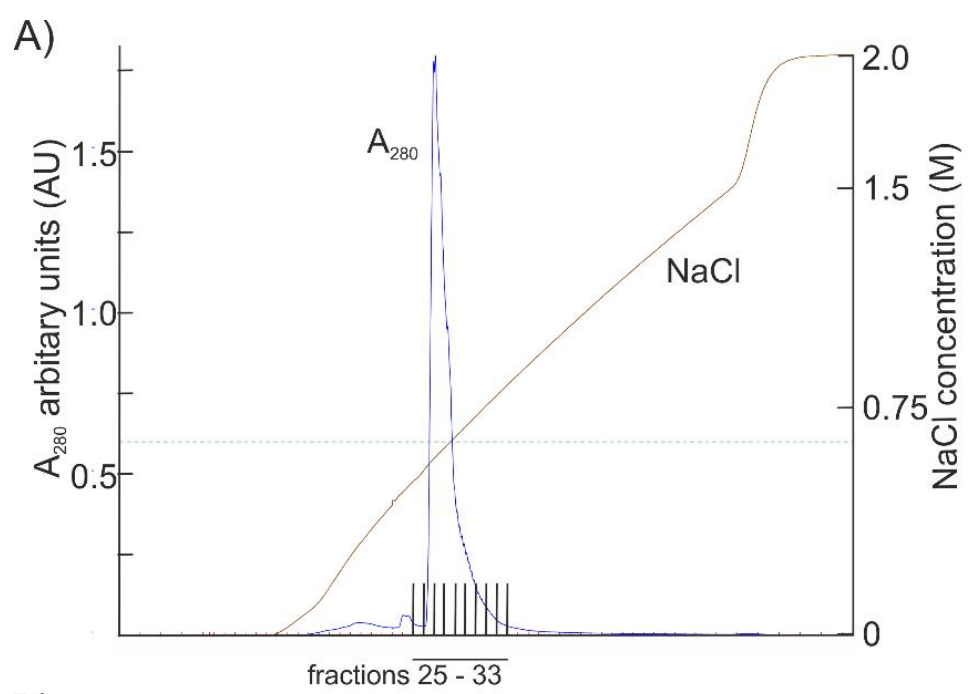

B)

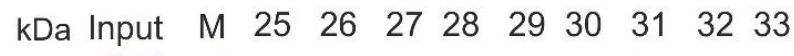

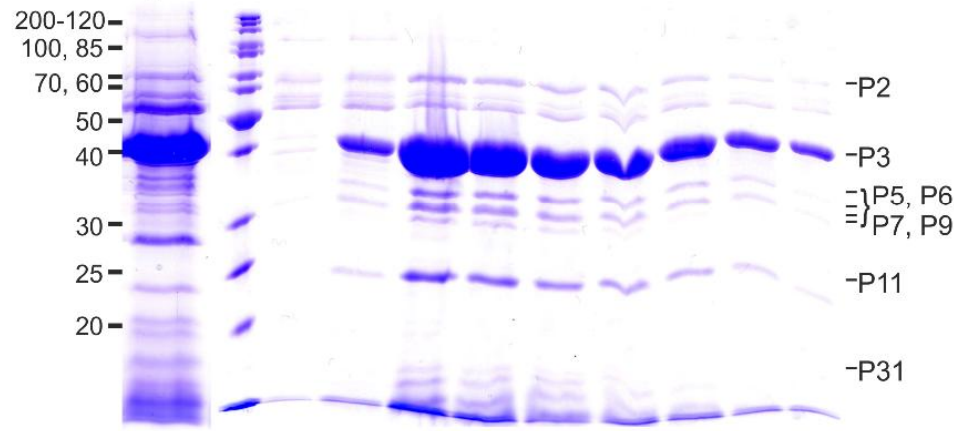

C)

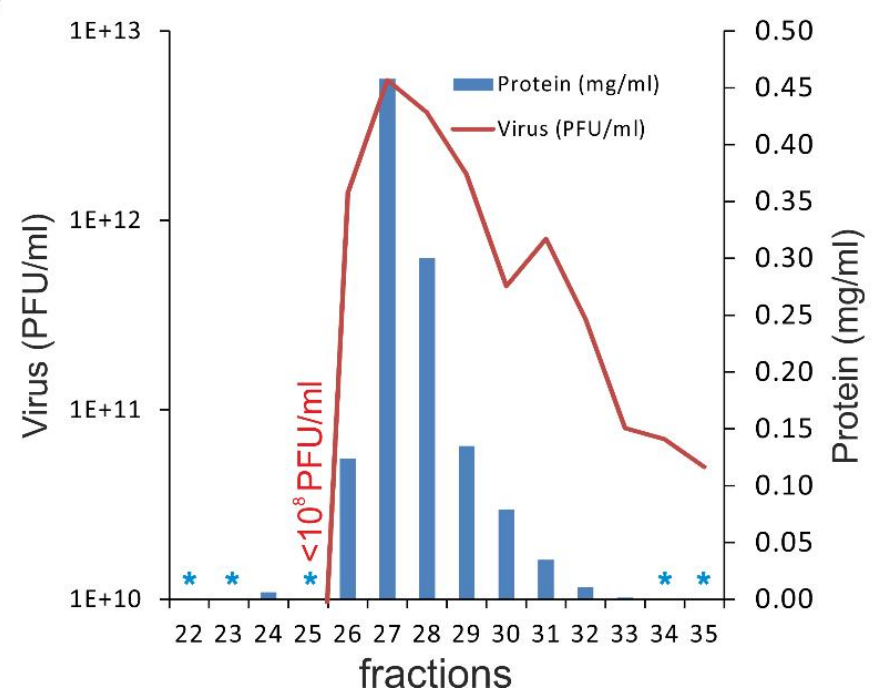

Fig. 7. 
Supplementary figures S1-S9.

Eskelin et al., Asymmetric flow field flow fractionation methods for virus purification. 

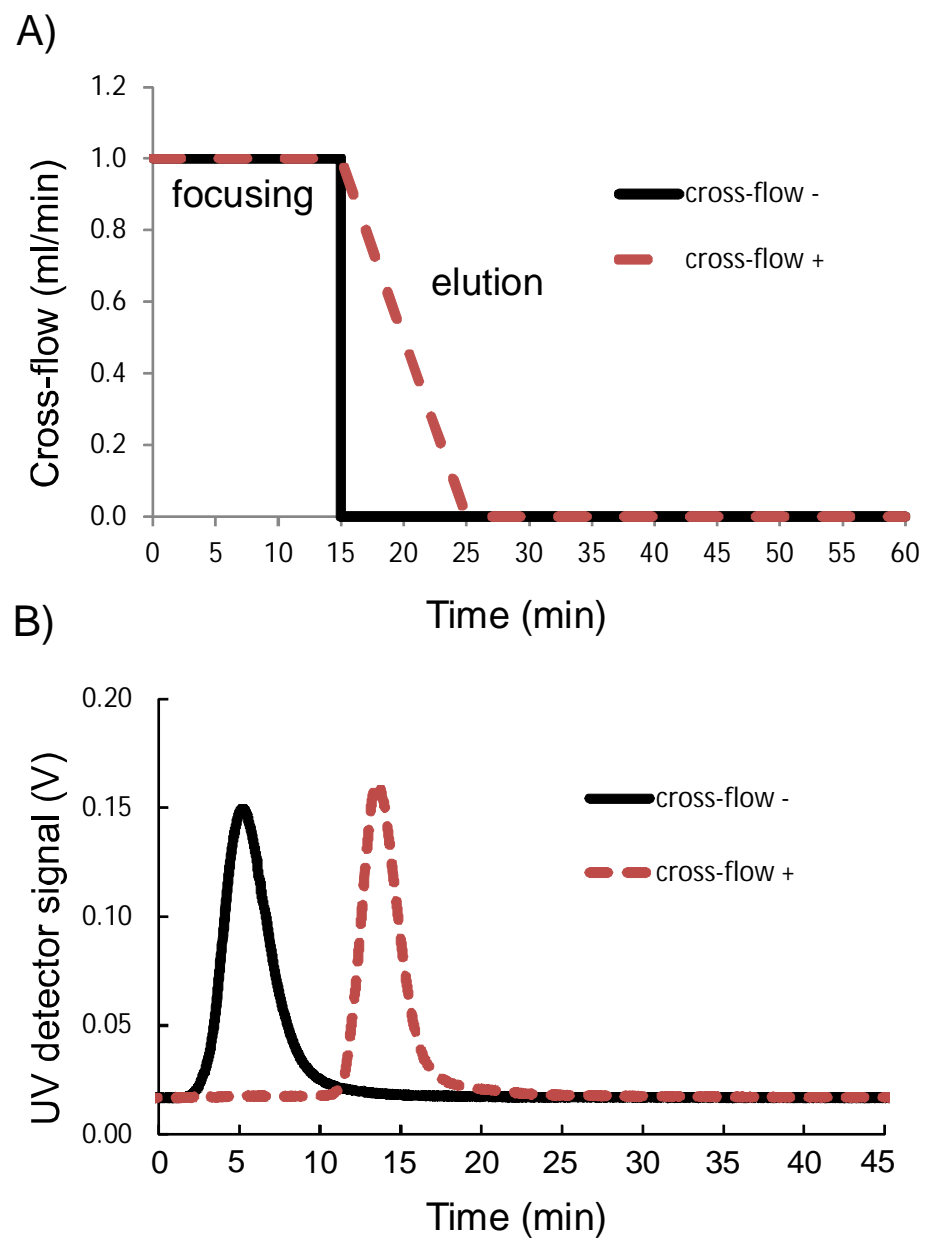

C)

\begin{tabular}{lcccc} 
& $\begin{array}{c}\text { Time } \\
\text { Fr }\end{array}$ & \multicolumn{1}{c}{$\begin{array}{c}\mathbf{A}_{\mathbf{2 8 0}} \\
\text { (min) }\end{array}$} & \multicolumn{1}{c}{$\begin{array}{c}\mathbf{A}_{\mathbf{2 8 0}} \\
\text { cross-flow }- \text { cross-flow + }\end{array}$} \\
\hline 1 & $0-5$ & 0.520 & 0.010 \\
2 & $5-10$ & 1.620 & 0.014 \\
3 & $10-15$ & 0.172 & 1.380 \\
4 & $15-20$ & 0.029 & 0.788 \\
5 & $20-25$ & 0.012 & 0.131 \\
6 & $25-30$ & 0.000 & 0.042 \\
7 & $30-35$ & & 0.036 \\
8 & $35-40$ & & 0.026 \\
9 & $40-45$ & & 0.028 \\
sum & & $\mathbf{2 . 3 1}$ & $\mathbf{2 . 3 0}$ \\
Input & & 2.21 & 2.21 \\
yield \% & & $\mathbf{1 0 5}$ & $\mathbf{1 0 4}$
\end{tabular}

Supplementary figure S1. PRD1 does not interact with the $100 \mathrm{kDa} R \mathrm{R}$ membrane.

A) AF4 elution programs without applied cross-flow (solid black) or with linear elution gradient (red dashed). Vout was $0.2 \mathrm{ml} / \mathrm{min}$. Tf was $15 \mathrm{~min}$.

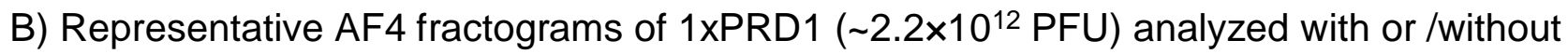
applied cross-flow. $T_{f}(15 \mathrm{~min})$ was deducted from the time scale. UV-detector monitored UV signal at $260 \mathrm{~nm}$ in volts $(\mathrm{V})$ with a 0.01 range setting.

C) $A_{280}$ measurements from collected fractions (each $1 \mathrm{ml}, 5 \mathrm{~min}$ ) and $A_{280}$ recovery yields

(\%) calculated for the three peak fractions (boxed). 
A)

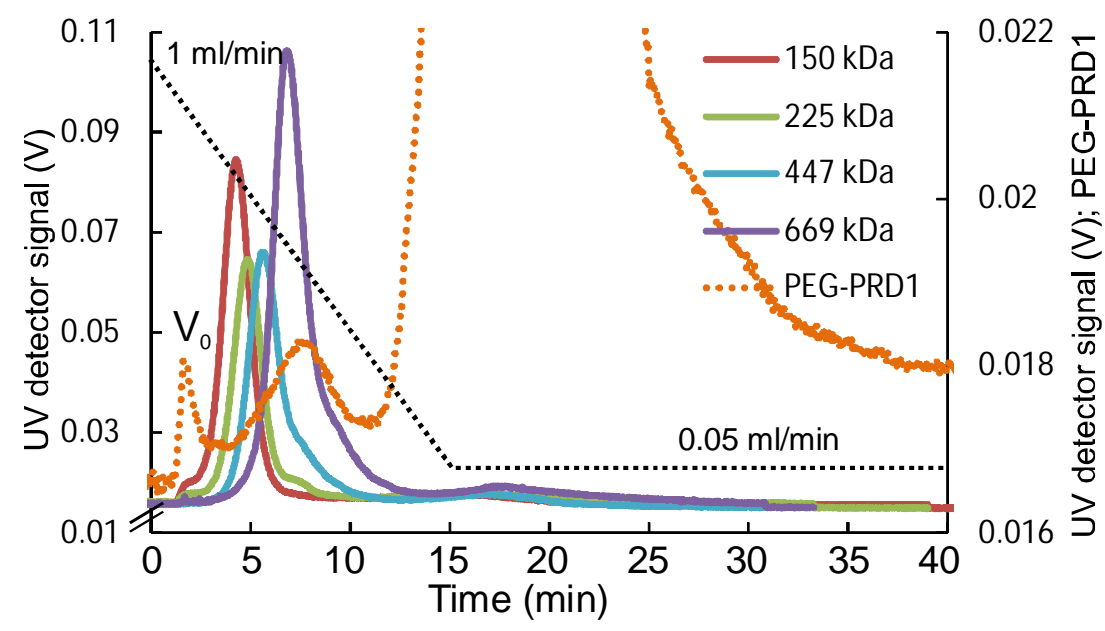

B)

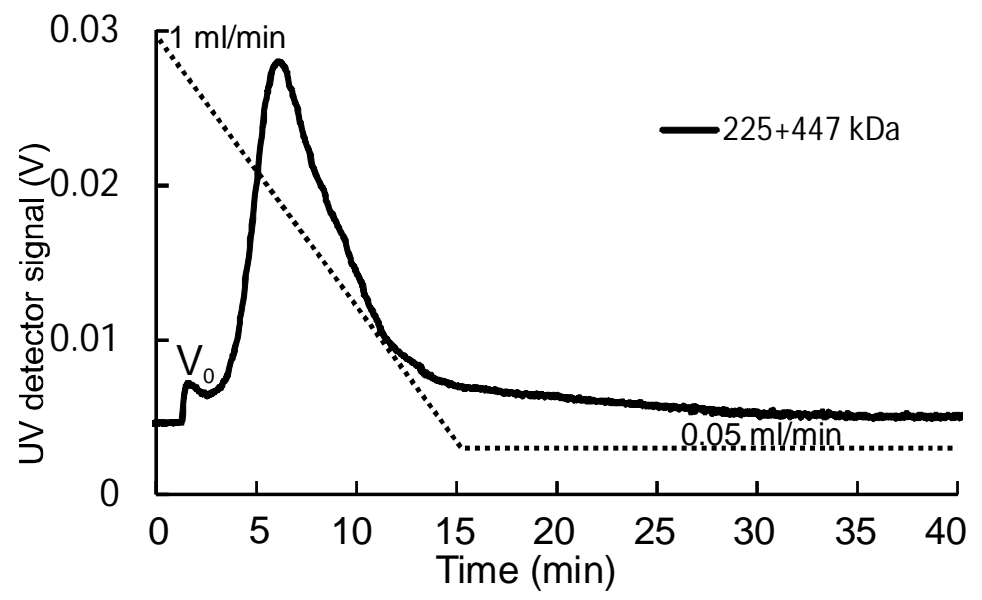

Supplementary figure S2: AF4 fractionation of standard proteins with varying molecular weights. A) Fractograms of standard proteins (left y-axis) were compared to PEG-PRD1 sample (right $\mathrm{y}$-axis), $\mathrm{tf}(15 \mathrm{~min}$ ) was deducted from the time scale. UV-detector monitored UV signal at $260 \mathrm{~nm}$ in volts $(\mathrm{V})$. The $15 \mathrm{~min}$ linear elution program from $1 \mathrm{ml} / \mathrm{min}$ to $0.05 \mathrm{ml} / \mathrm{min}$ is shown with dashed black line. Channel flow rate $\left(V_{\text {out }}\right)$ was $0.2 \mathrm{ml} / \mathrm{min}$. B) Fractogram of a mixture of 225 and $447 \mathrm{kDa}$ standard proteins. The elution program is the same as in A) (dashed black line). $V_{0}$ is the void peak that eluted at $\sim 1.8 \mathrm{~min}$. 
A)

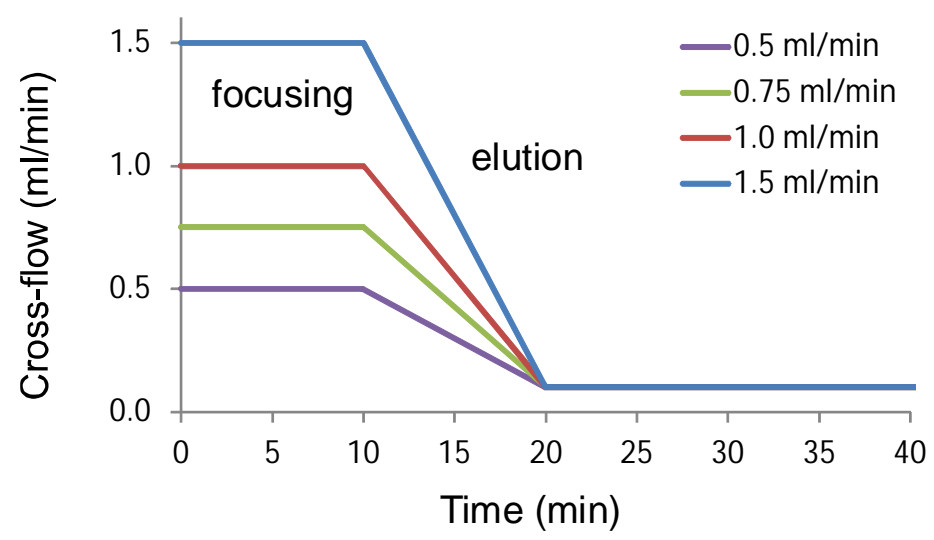

B)

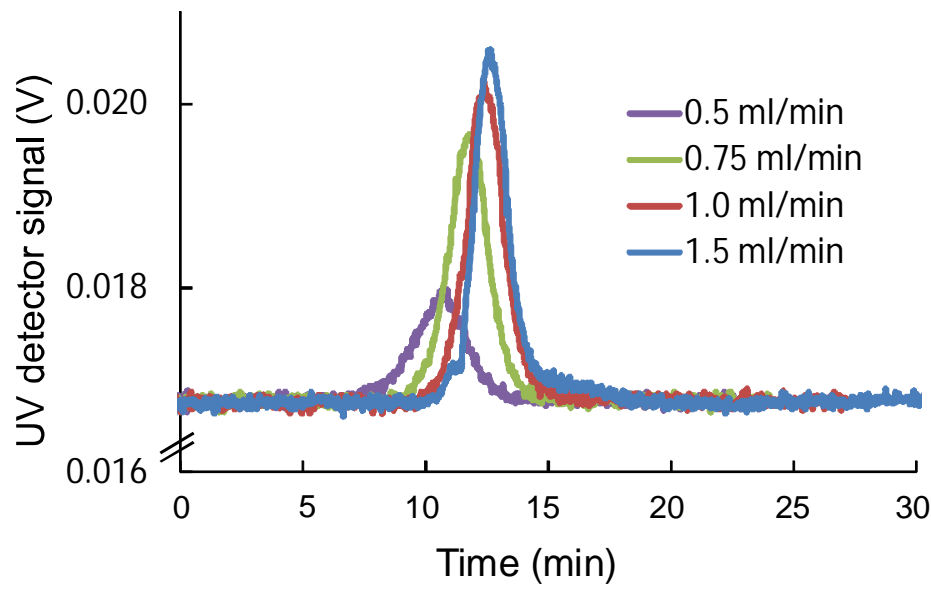

Supplementary figure S3. Effect of cross-flow on PRD1 recovery and resolution.

A) AF4 elution programs with varying cross-flows. Focusing time ( $\left.\mathrm{t}_{\mathrm{f}}\right)$ was $15 \mathrm{~min}$. Channel flow (Vout) was $0.2 \mathrm{ml} / \mathrm{min}$.

B) Representative fractograms of $1 \times$ PRD1 ( $2 \times 10^{11}$ PFUs) with varying cross-flow rates, tf was deducted from the time scale. UV-detector monitored UV signal at $260 \mathrm{~nm}$ in volts (V) with a 0.1 range setting. 
A)

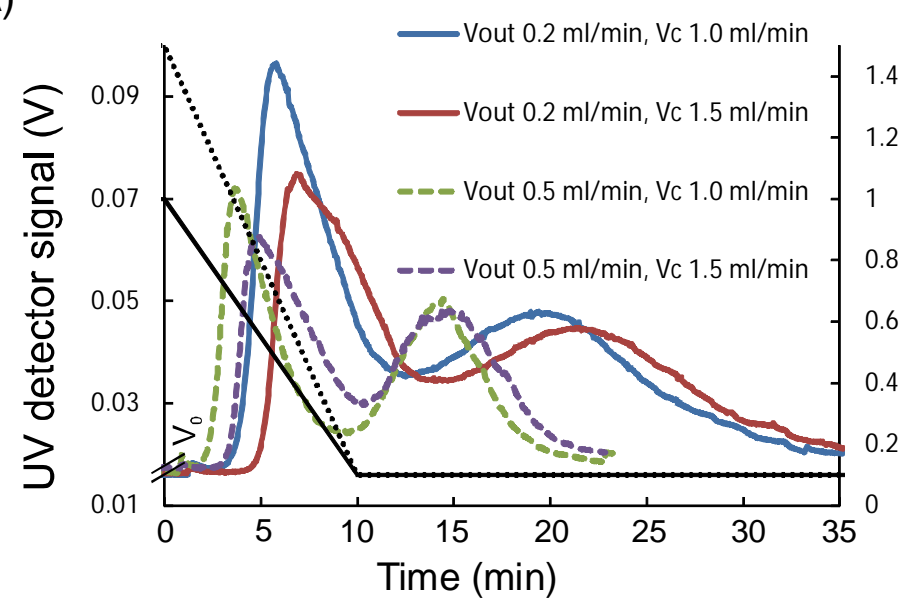

B)

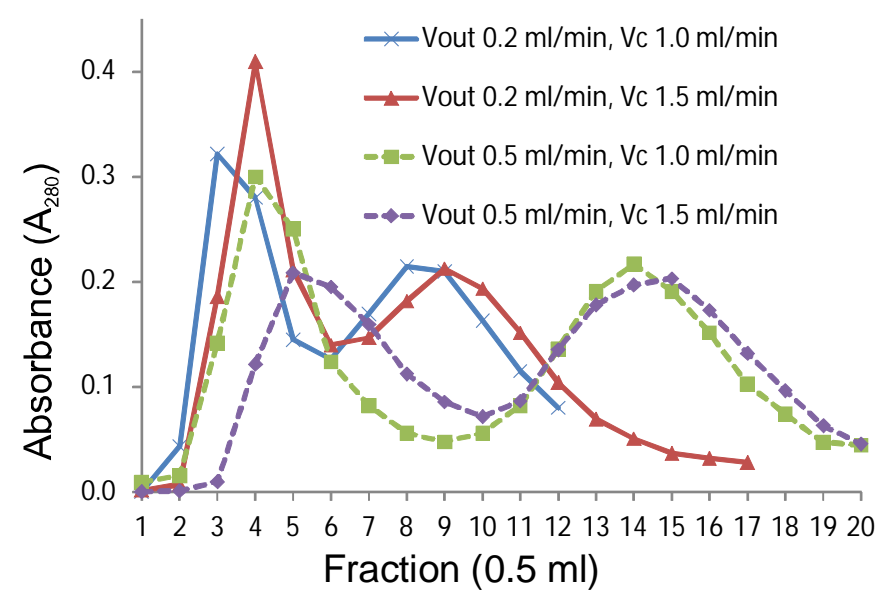

C)

\begin{tabular}{|c|c|c|c|c|c|c|c|c|c|}
\hline \multirow[b]{2}{*}{$\begin{array}{l}\text { Channel \& initial } \\
\text { cross-flow rates }\end{array}$} & & \multirow[b]{2}{*}{$\begin{array}{c}\text { Volume } \\
\text { (ml) }\end{array}$} & \multicolumn{3}{|c|}{ Virus } & \multicolumn{3}{|c|}{$\begin{array}{l}\text { Protein } \\
A_{280} A_{28 \text { Vield }}\end{array}$} & \multirow{2}{*}{$\begin{array}{c}\text { Purity } \\
\text { PFU/A }\end{array}$} \\
\hline & & & $\mathrm{PFU} / \mathrm{ml}$ & PFU & $\begin{array}{l}\text { PFU yield } \\
\text { (\%) }\end{array}$ & $A_{280} / \mathrm{ml}$ & $\begin{array}{l}A_{280} \\
\text { units }\end{array}$ & $\begin{array}{c}A_{280} \text { yield } \\
(\%)\end{array}$ & \\
\hline $\mathrm{V}_{\text {out }} 0.2 \mathrm{ml} / \mathrm{min}$ & Peak 1 (fr 3-5) & 1.5 & $2.6 \mathrm{E}+08$ & $3.9 E+08$ & 0.1 & 0.50 & 0.75 & 15 & \\
\hline $\mathrm{V}_{\mathrm{c}} 1.0 \mathrm{ml} / \mathrm{min}$ & Peak 2 (fr 6-10) & 2.5 & $1.7 \mathrm{E}+11$ & 4. $3 \mathrm{E}+11$ & 74 & 0.35 & 0.88 & 18 & $4.8 \mathrm{E}+11$ \\
\hline $\mathrm{V}_{\text {out }} 0.2 \mathrm{ml} / \mathrm{min}$, & peak 1 (fr 3-5) & 1.5 & $2.6 \mathrm{E}+08$ & $3.9 E+08$ & 0.1 & 0.54 & 0.81 & 17 & \\
\hline $\mathrm{V}_{\mathrm{c}} 1.5 \mathrm{ml} / \mathrm{min}$ & Peak 2 (fr 6-10) & 2.5 & $1.4 \mathrm{E}+11$ & $3.5 E+11$ & 61 & 0.35 & 0.87 & 18 & $4.0 \mathrm{E}+11$ \\
\hline $\mathrm{V}_{\text {out }} 0.5 \mathrm{ml} / \mathrm{min}$, & Peak 1 (fr 4-9) & 3.0 & $7.1 \mathrm{E}+07$ & $2.1 \mathrm{E}+08$ & 0.0 & 0.29 & 0.88 & 18 & \\
\hline $\mathrm{V}_{\mathrm{c}} 1.0 \mathrm{ml} / \mathrm{min}$ & Peak 2 (fr 12-18) & 3.5 & $1.3 \mathrm{E}+11$ & 4. $6 \mathrm{E}+11$ & 79 & 0.32 & 1.12 & 23 & $4.1 \mathrm{E}+11$ \\
\hline $\mathrm{V}_{\text {out }} 0.5 \mathrm{ml} / \mathrm{min}$, & Peak 1 (fr 3-8) & 3.0 & $3.9 \mathrm{E}+07$ & $1.2 \mathrm{E}+08$ & 0.0 & 0.32 & 0.95 & 20 & \\
\hline $\mathrm{V}_{\mathrm{c}} 1.5 \mathrm{ml} / \mathrm{min}$ & Peak 2 (fr 11-17) & 3.5 & $1.4 \mathrm{E}+11$ & $4.8 \mathrm{E}+11$ & 82 & 0.31 & 1.07 & 22 & $4.4 \mathrm{E}+11$ \\
\hline & Input & 0.1 & $5.8 \mathrm{E}+12$ & $5.8 \mathrm{E}+11$ & 100.0 & 48.6 & 4.86 & 100 & $1.2 \mathrm{E}+11$ \\
\hline
\end{tabular}

D)

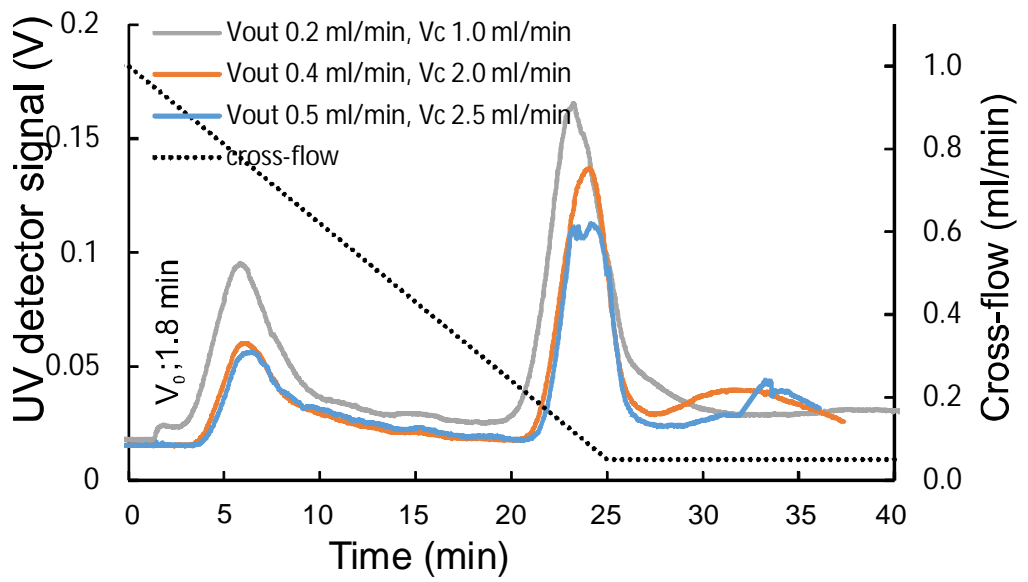

Supplementary figure S4. Effect of channel ( $\left.\mathrm{V}_{\text {out }}\right)$ and cross-flow $\left(\mathrm{V}_{\mathrm{c}}\right)$ rate on resolution.

A) Representative AF4 fractograms of PEG-PRD1 sample ( 6×1011 PFUs). Elution program: 15 min focusing, followed by elution with a 10 min linearly decaying cross-flow gradient ramping from 1.0 (solid, black) or $1.5 \mathrm{ml} / \mathrm{min}$ (dashed, black) to $0.1 \mathrm{ml} / \mathrm{min}$; channel flow rate was 0.2 or $0.5 \mathrm{ml} / \mathrm{min}$. UV-detector monitored UV signal at $260 \mathrm{~nm}$ in volts $(\mathrm{V})$ with a 0.01 range setting. $\mathrm{V}_{0}$ is the void peak that eluted at $\sim 1 \mathrm{~min}\left(\mathrm{~V}_{\text {out }} 0.5 \mathrm{ml} / \mathrm{min}\right)$ or $\sim 1.4 \mathrm{~min}\left(\mathrm{~V}_{\text {out }} 0.2 \mathrm{ml} / \mathrm{min}\right)$; t was deducted from the time scale.

B) A280 measurements of the fractions that were collected from the beginning of elution.

C) Virus and protein amounts of the peaks.

D) Representative AF4 fractograms from analysis of PRD1 lysate using flow conditions yielding $\mathrm{V}_{\mathrm{c}} / \mathrm{V}_{\text {out }}$ ratio of 5.0 . Elution program from $1 \mathrm{ml} / \mathrm{min}$ to $0.1 \mathrm{ml} / \mathrm{min}$ is shown with black dashed line. UV-detector monitored UV signal at $260 \mathrm{~nm}$ in volts $(\mathrm{V})$ with a 0.001 range setting. $V_{0}$ is the void peak; tf $(15 \mathrm{~min})$ was deducted from the time scale. 
A)

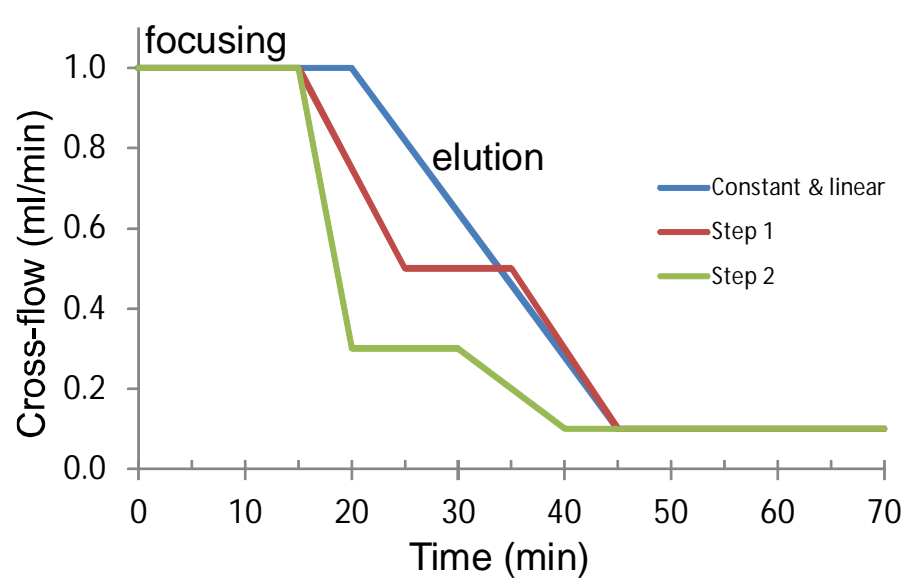

C)

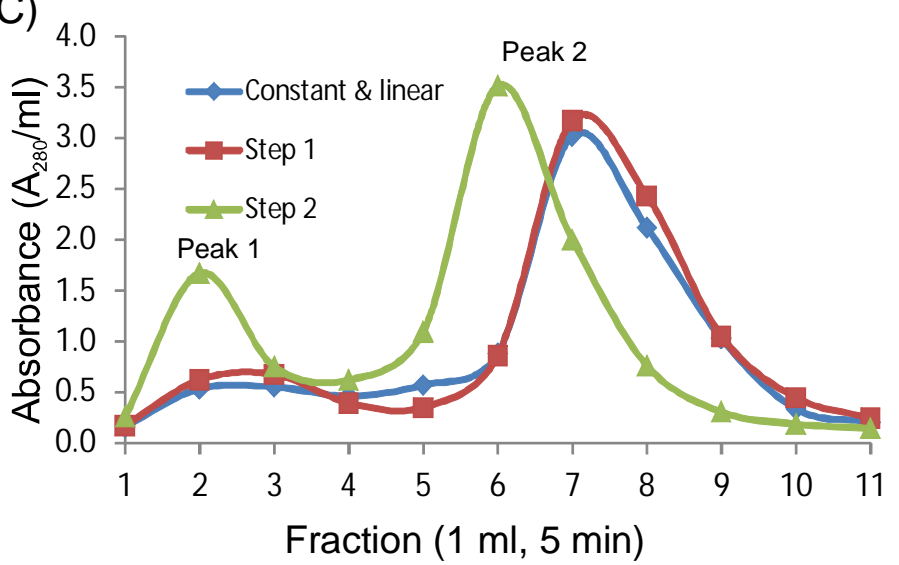

B)

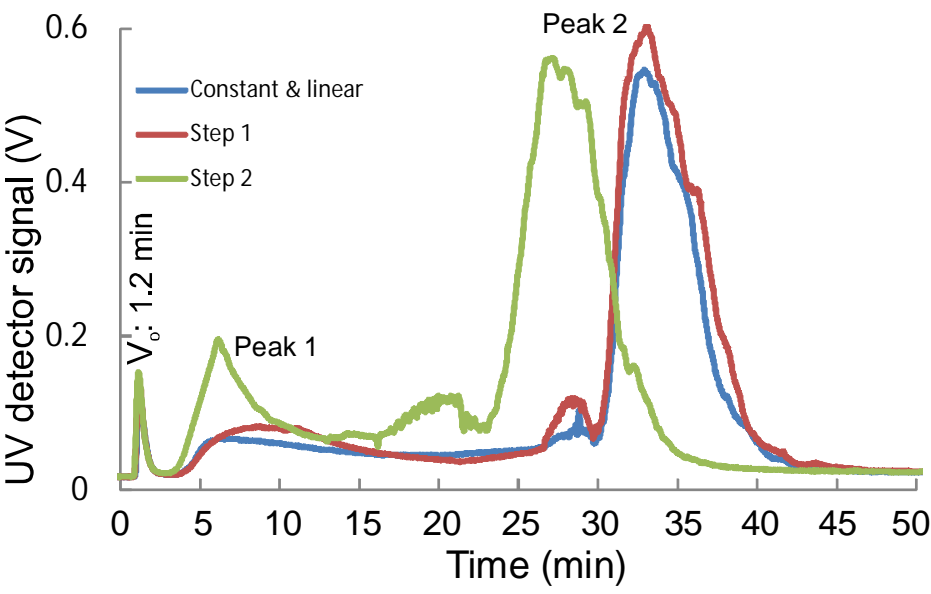

D)

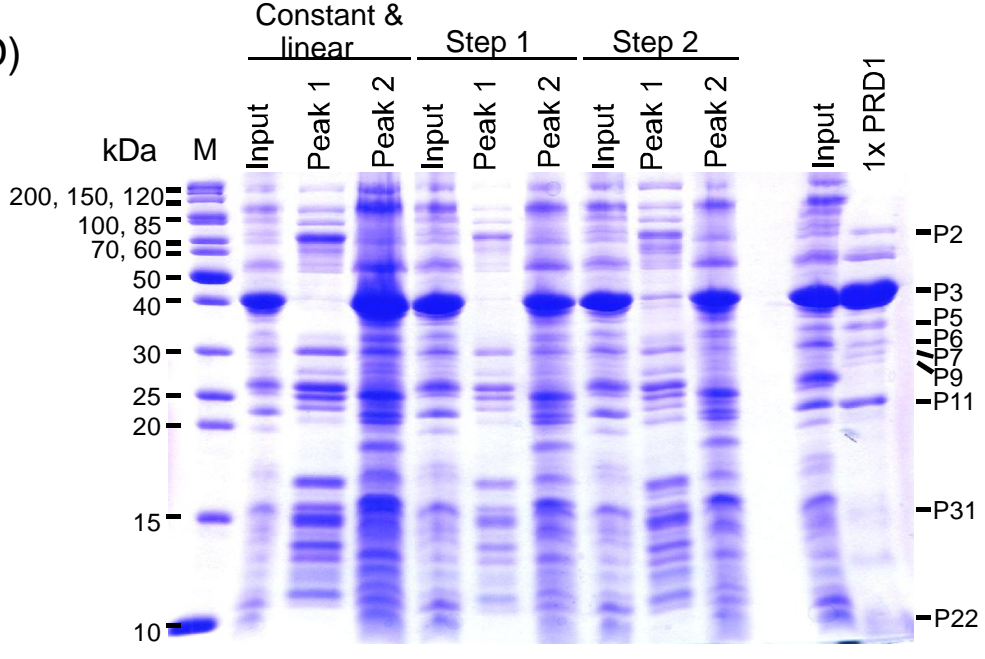

E)

\begin{tabular}{|c|c|c|c|c|c|c|c|c|c|c|c|c|c|}
\hline \multirow[b]{2}{*}{$\begin{array}{l}\text { Gradient } \\
\text { type }\end{array}$} & & \multirow[b]{2}{*}{$\begin{array}{c}\text { Volume } \\
\text { (ml) }\end{array}$} & \multicolumn{3}{|c|}{ Virus } & \multicolumn{3}{|c|}{ Protein (Bradford) } & \multirow{2}{*}{$\begin{array}{c}\text { Purity } \\
\text { PFU/mg } \\
\text { protein }\end{array}$} & \multicolumn{3}{|c|}{ Protein $\left(A_{280}\right)$} & \multirow{2}{*}{$\begin{array}{c}\text { Purity } \\
\text { PFU/ } \\
\text { A } 280\end{array}$} \\
\hline & & & PFU/ml & PFU & $\begin{array}{c}\text { PFU yield } \\
(\%)\end{array}$ & $\begin{array}{c}\text { Prot } \\
(\mu \mathrm{g} / \mathrm{ml})\end{array}$ & $\begin{array}{l}\text { Prot } \\
(\mathrm{mg})\end{array}$ & $\begin{array}{c}\text { Yield } \\
(\%)\end{array}$ & & $\mathrm{A}_{280} / \mathrm{ml}$ & $\begin{array}{l}A_{280} \\
\text { units } \\
\end{array}$ & $\begin{array}{c}\mathbf{A}_{280} \\
\text { yield } \\
(\%)\end{array}$ & \\
\hline \multirow{2}{*}{$\begin{array}{l}\text { Constant } \\
\text { \& linear }\end{array}$} & Peak 1 & 2 & $4.8 \mathrm{E}+08$ & $9.5 \mathrm{E}+08$ & 0.05 & 72 & 0.14 & 6 & $6.6 \mathrm{E}+09$ & 0.5 & 1.1 & 4 & $8.8 \mathrm{E}+08$ \\
\hline & Peak 2 & 4 & $4.9 \mathrm{E}+11$ & $2.0 \mathrm{E}+12$ & 107 & 87 & 0.35 & 14 & $5.6 \mathrm{E}+12$ & 1.8 & 7.1 & 25 & $2.8 \mathrm{E}+11$ \\
\hline \multirow[t]{2}{*}{ Step 1} & Peak 1 & 2 & $7.9 \mathrm{E}+08$ & $1.6 \mathrm{E}+09$ & 0.09 & 172 & 0.34 & 13 & $4.6 \mathrm{E}+09$ & 0.6 & 1.3 & 5 & $1.2 \mathrm{E}+09$ \\
\hline & Peak 2 & 4 & $4.9 \mathrm{E}+11$ & $2.0 \mathrm{E}+12$ & 107 & 189 & 0.76 & 30 & $2.6 \mathrm{E}+12$ & 1.9 & 7.4 & 26 & $2.6 \mathrm{E}+11$ \\
\hline \multirow[t]{3}{*}{ Step 2} & Peak 1 & 2 & $1.7 \mathrm{E}+10$ & $3.3 \mathrm{E}+10$ & 1.8 & 212 & 0.42 & 17 & $7.8 \mathrm{E}+10$ & 1.2 & 2.4 & 8 & $1.4 \mathrm{E}+10$ \\
\hline & Peak 2 & 4 & $5.9 \mathrm{E}+11$ & $2.3 \mathrm{E}+12$ & 128 & 215 & 0.86 & 34 & $2.7 \mathrm{E}+12$ & 1.8 & 7.4 & 26 & $3.2 \mathrm{E}+11$ \\
\hline & Input & 0.5 & $3.7 \mathrm{E}+12$ & $1.8 \mathrm{E}+12$ & 100 & 5100 & 2.55 & 100 & $7.2 \mathrm{E}+11$ & 57 & 29 & 100 & $6.4 \mathrm{E}+10$ \\
\hline
\end{tabular}

Supplementary figure S5. Effect of elution gradient type on resolution and PRD1 recovery.

A) Elution programs: i) (linear) 5 min constant cross-flow followed by a 25 min linear elution gradient from 1 $\mathrm{ml} / \mathrm{min}$ to $0.1 \mathrm{ml} / \mathrm{min}$; ii) (step 1) $10 \mathrm{~min} \mathrm{ramp} \mathrm{from} 1 \mathrm{ml} / \mathrm{min}$ to $0.5 \mathrm{ml} / \mathrm{min}$, followed by constant cross-flow for 10 min and $10 \mathrm{~min} \mathrm{ramp} \mathrm{to} 0.1 \mathrm{ml} / \mathrm{min}$; iii) (step 2) $5 \mathrm{~min} \mathrm{ramp}$ from $1 \mathrm{ml} / \mathrm{min}$ to $0.3 \mathrm{ml} / \mathrm{min}$ followed by constant cross-flow for $10 \mathrm{~min}$ and then $10 \mathrm{~min}$ ramp to $0.1 \mathrm{ml} / \mathrm{min}$.

B) Representative AF4 fractograms of PEG-PRD1 ( $2 \times 10^{12}$ PFUs). $T_{f}$ was deducted from the time scale. UVdetector monitored UV signal at $260 \mathrm{~nm}$ in volts $(\mathrm{V})$ with a 0.01 range setting. $\mathrm{V}_{0}$ is the void peak.

C) $A_{280}$ measurements of fractions collected from the beginning of elution.

D) SDS-PAGE gel analysis of proteins $(10 \mu \mathrm{g})$ from pooled fractions 2-3 from the first peak, pooled fractions 58 or 6-9 from the second peak, and the PEG-PRD1 input $(10 \mu \mathrm{g})$. Proteins were visualized with Coomassie stain. M: protein standards; purification control 1xPRD1 $(10 \mu \mathrm{g})$ with the most abundant PRD1 virion proteins indicated.

E) Recovery and purity of AF4 purified PEG-PRD1 from assayed protein and virus content of pooled peak fractions. 

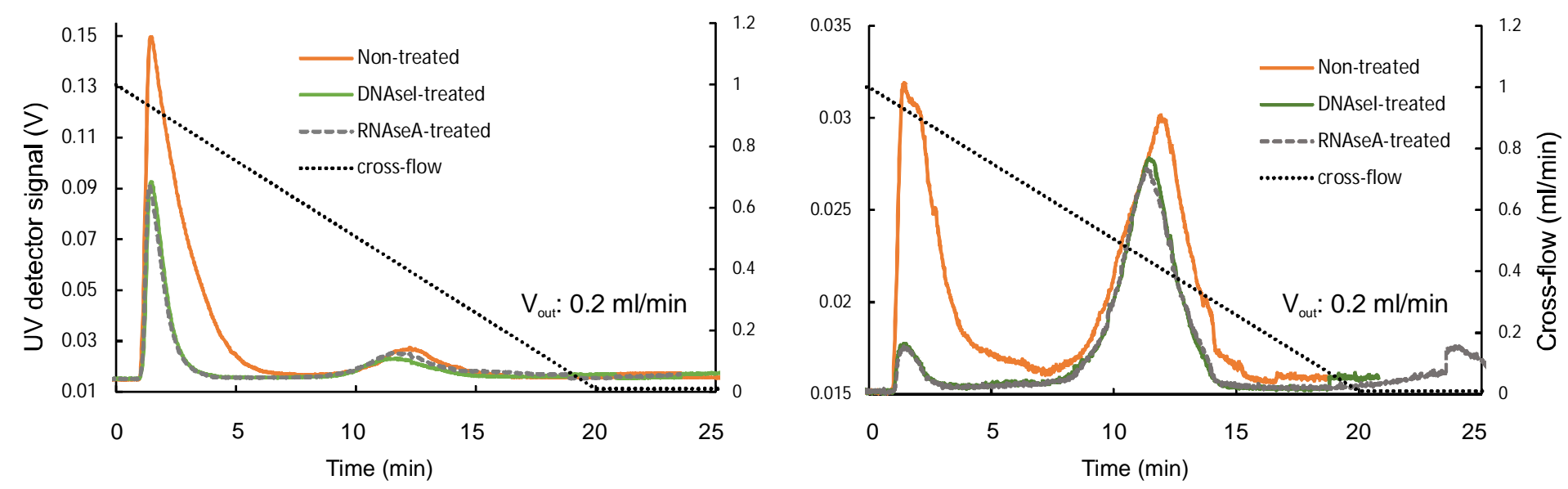

Supplementary figure S6. AF4 analysis of DNAsel and RNAseA treated PRD1 samples. Please, note that a $250 \mu \mathrm{m}$ spacer was used. A) Representative fractograms are shown for non-treated lysate and lysate $\left(3^{*} 10^{11}\right.$ PFUs) that was treated with DNAse I $(50 \mu \mathrm{g} / \mathrm{ml})$ or RNAse A $(30 \mu \mathrm{g} / \mathrm{ml})$ for $30 \mathrm{~min}$ at $37^{\circ} \mathrm{C}$ prior AF4 analysis. Equal volumes of lysates $(1 \mathrm{ml})$ were analysed. UV-detector monitored UV signal at $280 \mathrm{~nm}$ in volts (V) (left y-axis) and 0.001 range setting. Elution program is shown on the right $y$-axis (dashed black; t of $^{2} \mathrm{~min}$ is not shown); $V_{\text {out }}$ was $0.2 \mathrm{ml} / \mathrm{min}$. $V_{0}$ is the void peak that eluted at $\sim 1.5 \mathrm{~min}$. B) Representative fractograms are shown for PEG-NaCl-precipitated samples ( 1.4*1011 PFUs) prepared from non-treated lysate and DNAse I or RNAse A treated lysates. AF4 analysis was done as in A). UV-range setting was 0.01 . 
A)
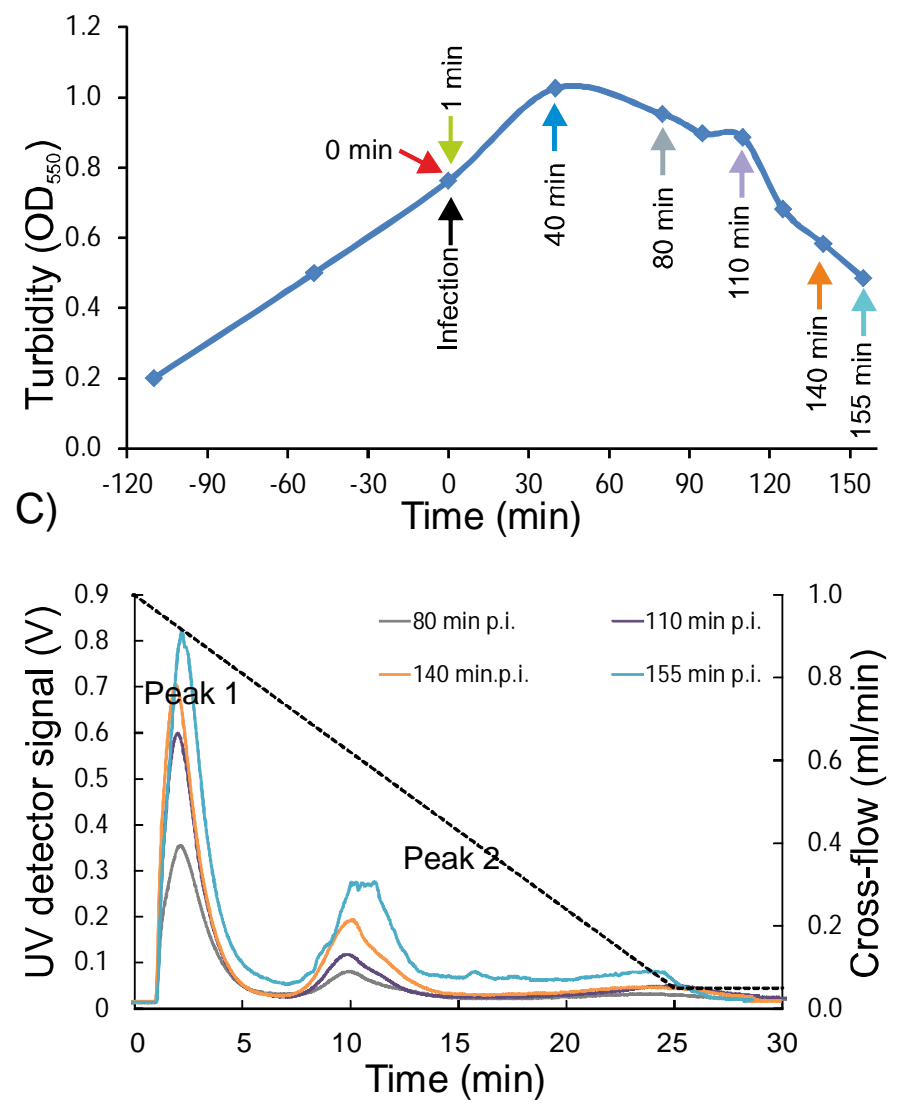

D)

\begin{tabular}{|c|c|c|c|c|c|c|c|c|c|}
\hline Näyte & $\begin{array}{c}\text { Time } \\
(\min \text { p.i. })\end{array}$ & $\mathrm{OD}_{550}$ & $\begin{array}{c}\text { Input } \\
\mathrm{PFU} / \mathrm{ml}\end{array}$ & $\begin{array}{c}\mathrm{Fr} .3 \\
\mathrm{PFU} / \mathrm{ml}\end{array}$ & $\begin{array}{l}\text { Fr. } 3 \\
\text { PFU }\end{array}$ & $\begin{array}{l}\text { PFU yield } \\
(\%)\end{array}$ & $\begin{array}{c}\text { Dilution } \\
\text { factor }\end{array}$ & $A_{280} / \mathrm{ml}$ & $\mathrm{PFU} / \mathrm{A}_{280}$ \\
\hline 0 & 0 & 0.76 & 0 & 0 & & & & & \\
\hline 1 & $1^{*}$ & 0.76 & $5.7 E+09$ & $1.4 \mathrm{E}+09$ & 1.1E+09 & 20 & 4.0 & & \\
\hline 2 & 40 & 1.03 & $6.9 E+09$ & $4.5 E+08$ & $3.6 \mathrm{E}+08$ & 5 & 15.3 & 0.005 & \\
\hline 3 & 80 & 0.95 & & & & & & 0.07 & \\
\hline 4 & 95 & 0.90 & $8.9 E+10$ & $6.5 \mathrm{E}+10$ & $5.2 \mathrm{E}+10$ & 58 & 1.4 & 0.13 & $5.2 \mathrm{E}+11$ \\
\hline 5 & 110 & 0.89 & & & & & & 0.16 & \\
\hline 6 & 125 & 0.68 & $1.7 \mathrm{E}+11$ & $2.0 \mathrm{E}+11$ & $1.6 \mathrm{E}+11$ & 94 & 0.9 & 0.23 & $8.8 \mathrm{E}+11$ \\
\hline 7 & 140 & 0.58 & $2.5 E+11$ & $1.6 \mathrm{E}+11$ & $1.3 \mathrm{E}+11$ & 52 & 1.5 & 0.22 & $7.3 \mathrm{E}+11$ \\
\hline 8 & 155 & 0.49 & $2.6 \mathrm{E}+11$ & $2.0 \mathrm{E}+11$ & $1.6 \mathrm{E}+11$ & 62 & 1.3 & 0.25 & $8.2 \mathrm{E}+11$ \\
\hline
\end{tabular}

Figure S7. AF4 analysis of PRD1 infection: one-step growth curve using $250 \mu \mathrm{m}$ spacer and RC with a 10 kDa MWCO.

A) Virus life cycle. Turbidity of PRD1 infected cultures was monitored at $\mathrm{OD}_{550}$. At time zero $\left(\mathrm{OD}_{550} \sim 0.8\right)$, cells were infected using a MOI of 10 . Coloured arrows indicate the time points analysed by AF4.

B) Representative fractograms from analysis of culture supernatants prior cell lysis. LB (Luria-Bertani media) control: the background signal from the growth media. UV-detector monitored UV signal at $260 \mathrm{~nm}$ in volts (V) with a 0.001 range setting (left $y$-axis). Elution program is shown on the right $y$-axis (dashed black); $\mathrm{t}_{\mathrm{f}}(15$ $\mathrm{min}$ ) was deducted from the time axis. $V_{\text {out }}$ was $0.2 \mathrm{ml} / \mathrm{min}$.

C) Selected fractograms from analysis of culture supernatants collected after the onset of cell lysis. Fractions $(0.8 \mathrm{ml})$ were collected. Please note the 20 -fold difference in UV signal intensity scale (left $y$-axis) between panels $\mathrm{B}$ and $\mathrm{C}$.

D) Recovery and purity of AF4 fractionated culture supernatants as determined by comparison of the number of infectious viruses and $A_{280}$ values for fractions 3 eluting at 8-12 min versus the virus concentration of corresponding input sample. 
Supplementary figure S8. Obtained fits based on the spherical fit showed good agreement of the model across the complete peak. Sphere model fit for the PEG-PRD1 virus particle at the beginning of the UV-peak ( $t_{r}$ $=23.0 \mathrm{~min})(\mathrm{A})$, at UV-peak maximum ( $\left.\mathrm{t}_{\mathrm{r}}=24.8 \mathrm{~min}\right)$, and at the end of the UV-peak ( $\left.\mathrm{t}_{\mathrm{r}}=26.8 \mathrm{~min}\right)$.

A)

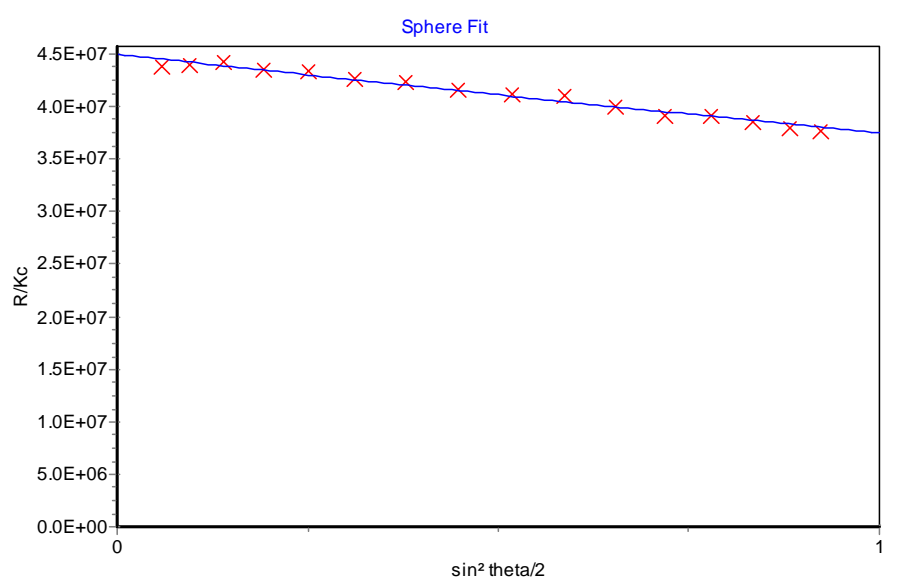

B)

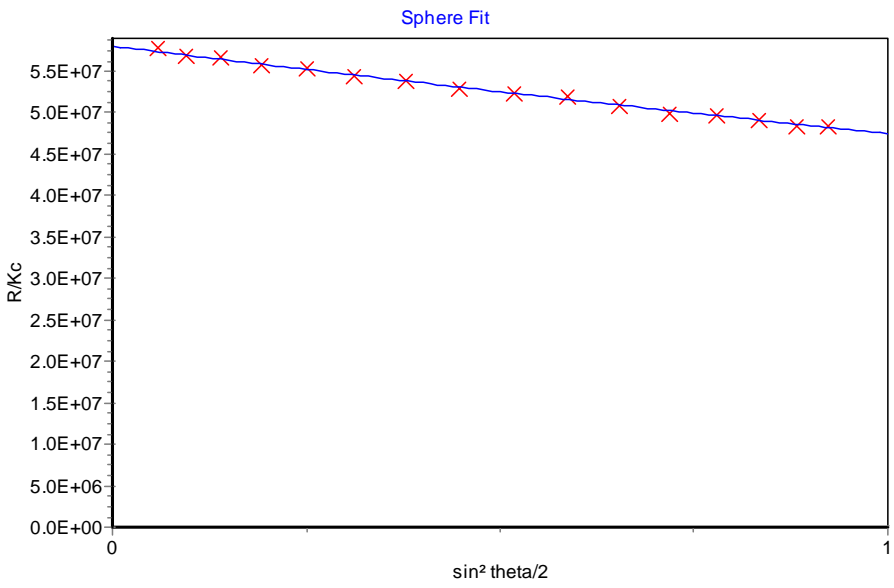

C)

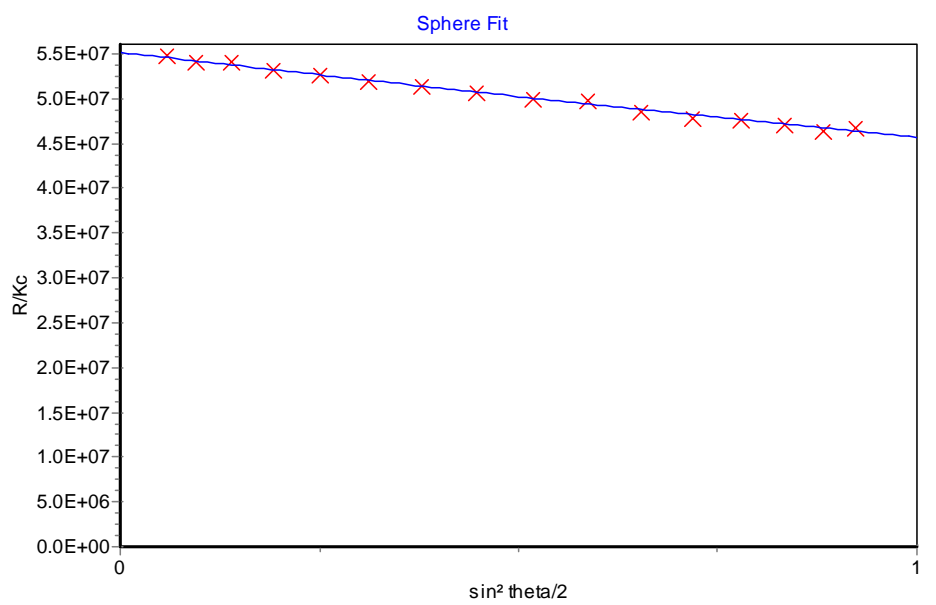


A)

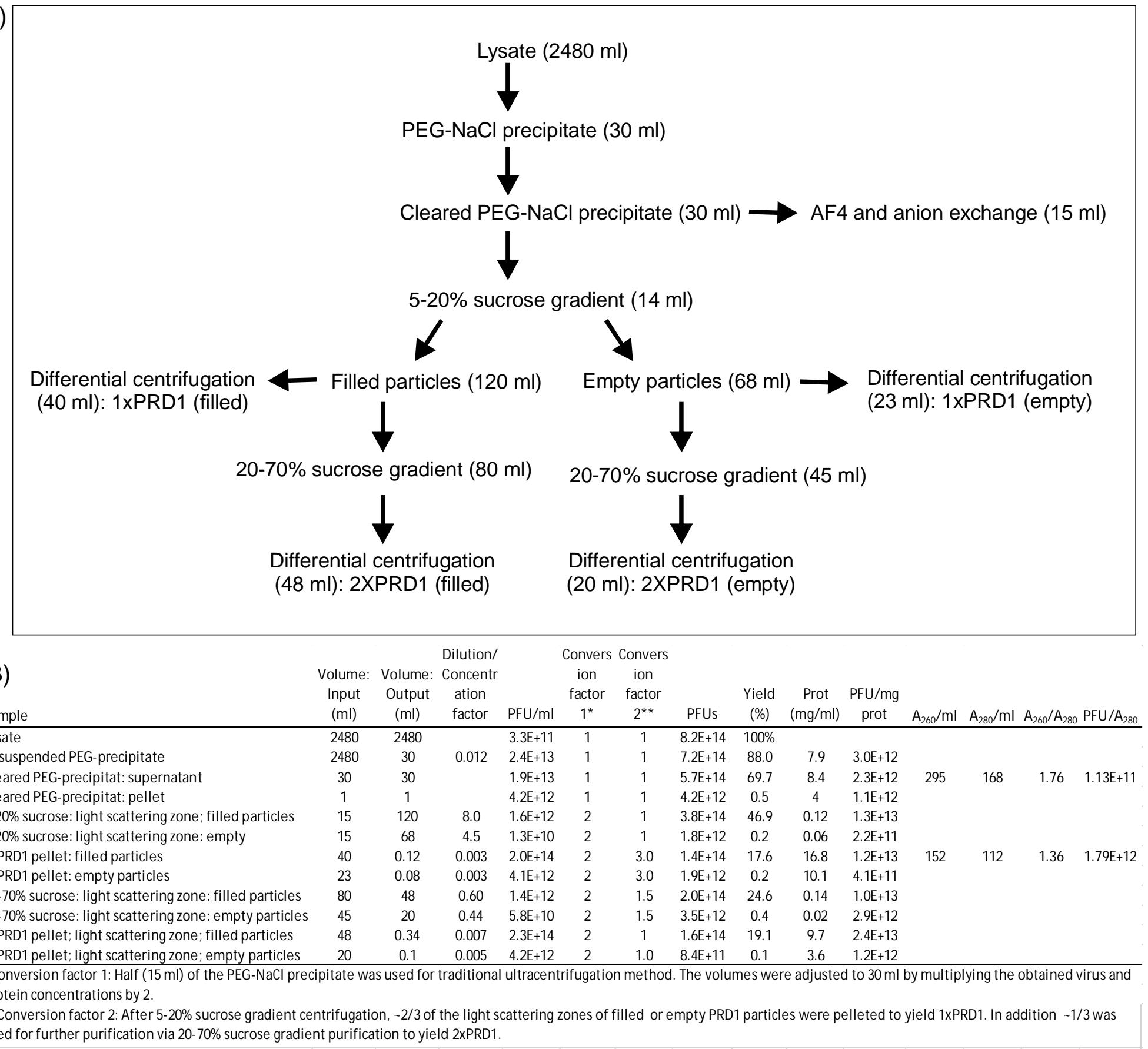

C)

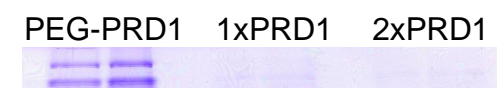

Figure S9. Traditional virus purification by subsequent ultracentrifugation steps.

A) Flow chart for traditional ultracentrifugation purification method. The volumes of different steps from one purification experiment are shown in parenthesis and were used in calculating the recoveries in B).

B) Virus concentrations, recoveries, and specific infectivities for different sub-steps of traditional purification. Recoveries were calculated to mirror the situation, in which the whole PEG-PRD1 sample would have been utilized to produce either 1XPRD1 or 2xPRD1.

C) Comparison of PEG-PRD1, 1xPRD1 and 2xPRD1 in Coomassie stained SDS-PAGE gel. Analysed protein amounts were 5 and $10 \mu \mathrm{g}$. 